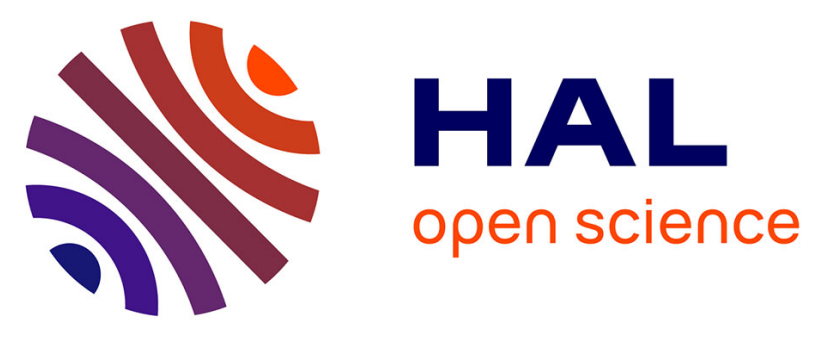

\title{
Potential of preventive bioremediation to reduce environmental contamination by pesticides in an agricultural context: A case study with the herbicide
} $2,4-\mathrm{D}$

Louis Carles, Fabrice Martin-Laurent, Marion Devers, Aymé Spor, Nadine Rouard, Jérémie Beguet, Pascale Besse-Hoggan, Isabelle Batisson

\section{To cite this version:}

Louis Carles, Fabrice Martin-Laurent, Marion Devers, Aymé Spor, Nadine Rouard, et al.. Potential of preventive bioremediation to reduce environmental contamination by pesticides in an agricultural context: A case study with the herbicide 2,4-D. Journal of Hazardous Materials, 2021, 416, pp.125740. 10.1016/j.jhazmat.2021.125740 . hal-03237156

\author{
HAL Id: hal-03237156 \\ https://hal.uca.fr/hal-03237156
}

Submitted on 26 May 2021

HAL is a multi-disciplinary open access archive for the deposit and dissemination of scientific research documents, whether they are published or not. The documents may come from teaching and research institutions in France or abroad, or from public or private research centers.
L'archive ouverte pluridisciplinaire HAL, est destinée au dépôt et à la diffusion de documents scientifiques de niveau recherche, publiés ou non, émanant des établissements d'enseignement et de recherche français ou étrangers, des laboratoires publics ou privés.

\section{(ㄷ)(i)}

Distributed under a Creative Commons Attribution| 4.0 International License 
4 Louis Carles ${ }^{\mathrm{a}, \mathrm{b} *}$, Fabrice Martin-Laurent ${ }^{\mathrm{c}}$, Marion Devers ${ }^{\mathrm{c}}$, Aymé Spor ${ }^{\mathrm{c}}$, Nadine Rouard ${ }^{\mathrm{c}}$,

5 Jérémie Beguet $^{\mathrm{c}}$, Pascale Besse-Hoggan ${ }^{\mathrm{b}}$, Isabelle Batisson ${ }^{\mathrm{a}}$

6

7 a Université Clermont Auvergne, CNRS, Laboratoire Microorganismes : Génome et 8 Environnement (LMGE), F-63000 Clermont-Ferrand, France

9 b Université Clermont Auvergne, CNRS, Sigma Clermont, Institut de Chimie de Clermont10 Ferrand (ICCF), F-63000 Clermont-Ferrand, France

$11{ }^{c}$ Agroécologie, AgroSup Dijon, INRA, Univ. Bourgogne, Univ. Bourgogne Franche-

12 Comté, F-21000 Dijon, France

13

$14 *$ Corresponding author:

15 Dr. Louis Carles

16 Now at: Department of Environmental Toxicology (Utox), Swiss Federal Institute of Aquatic

17 Science and Technology (Eawag), Dübendorf, Switzerland.

18 Überlandstrasse 133

198600 Dübendorf

20 Switzerland

21 E-mail address: louis.carles@eawag.ch

22 Phone: +41587655449 
24

25

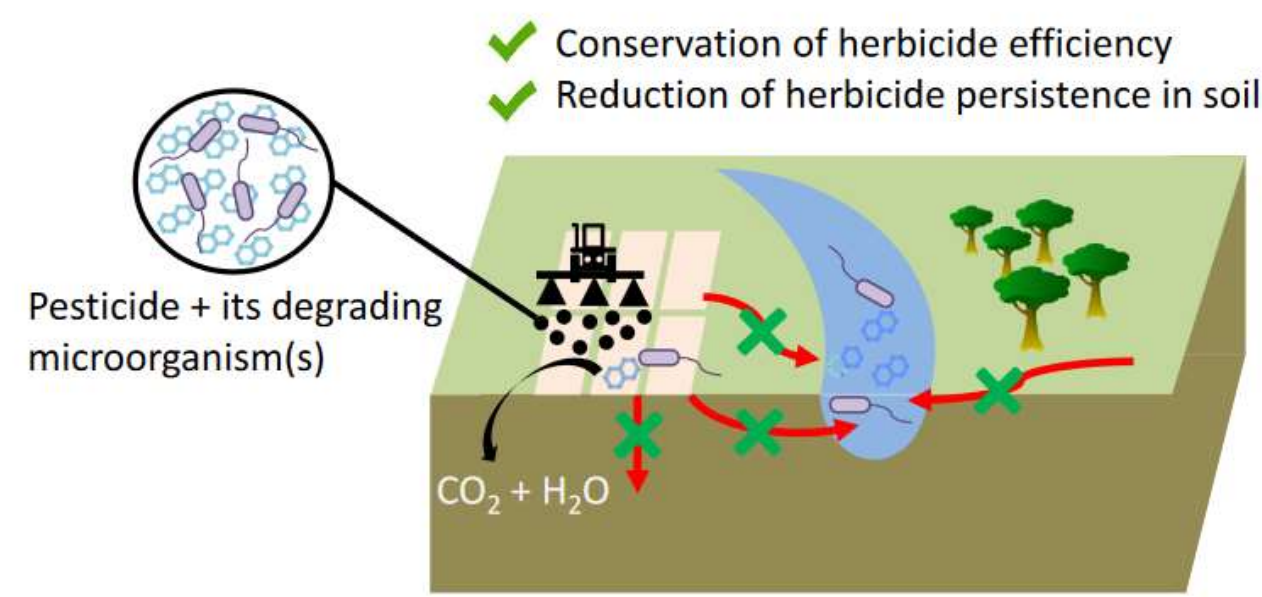

Limitation of pesticide transfer 


\section{Highlights}

38 - The preventive bioremediation is implemented and tested in an agricultural context

39 - The herbicidal efficiency was conserved in the preventive bioremediation treatment

40 - The preventive bioremediation reduced the pesticide persistence in soil

41 - The soil bacterial diversity was not affected by the inoculation of $C$. necator

42

43

44

45

46

47

48

49

50

51

52

53

54

55

56

57

58

59

60

61 
Abstract

63 One of the major problems with pesticides is linked to the non-negligible proportion of the

64 sprayed active ingredient that does not reach its intended target and contaminates environmental

65 compartments. Here, we have implemented and provided new insights to the preventive

66 bioremediation process based on the simultaneous application of the pesticide with pesticide-

67 degrading microorganisms to reduce the risk of leaching into the environment. This study

68 pioneers such a practice, in an actual farming practice context. The 2,4-dichlorophenoxyacetic

69 acid herbicide (2,4-D) and one of its bacterial mineralizing-strains (Cupriavidus necator

70 JMP134) were used as models.

71 The 2,4-D biodegradation was studied in soil microcosms planted with sensitive (mustard) 72 and insensitive (wheat) plants. Simultaneous application of a 2,4-D commercial formulation $73\left(\mathrm{DAM}^{\circledR}\right)$ at agricultural recommended doses with $10^{5}$ cells. $\mathrm{g}^{-1} \mathrm{dw}$ of soil of the JMP134 strain 74 considerably accelerated mineralization of the herbicide since its persistence was reduced 75 threefold for soil supplemented with the mineralizing bacterium without reducing the herbicide 76 efficiency. Furthermore, the inoculation of the Cupriavidus necator strain did not significantly 77 affect the $\alpha$ - and $\beta$-diversity of the bacterial community.

78 By tackling the contamination immediately at source, the preventive bioremediation process 79 proves to be an effective and promising way to reduce environmental contamination by 80 agricultural pesticides.

82 Keywords: 2,4-dichlorophenoxyacetic acid; Cupriavidus necator; environmental protection; 83 microbial ecotoxicology; mineralization. 


\section{Introduction}

85 One of the greatest challenges of the $21^{\text {st }}$ century is the development of innovative 86 approaches for sustainable agriculture as underlined by the recently launched farm to fork

87 European strategy (European Commission, 2020). Agricultural practices should not only satisfy

88 food demand but also avoid risks for the environment and human health. Accordingly,

89 authorities in some countries have introduced recommendations to reduce pesticide use, which

90 are regularly revised or have postponed their deadlines due to a lack of solutions to reach the

91 targeted quantitative objectives (e.g. the successive Ecophyto and Ecophyto II+ action plans in

92 France (Légifrance, 2019) or the Directives 2009/128/EC and 2019/782 for the European

93 Union). Indeed, alternative solutions to pesticide use, such as biocontrol or bio-stimulation, are

94 the subject of intense research but often their efficiency does not meet expectations (Syed Ab

95 Rahman et al., 2018; Ferreira et al., 2019; Köhl et al., 2019; Marian and Shimizu, 2019; Blake

96 et al., 2020), thus limiting their use in practice for the moment. For that reason, pesticide use

97 cannot yet be completely avoided and the remediation of pesticide-polluted environments is 98 still of great interest.

99 Biological remediation approaches, including phytoremediation (Del Buono et al., 2020) 100 and microbial remediation (Morillo and Villaverde, 2017; Ortiz-Hernandez et al., 2018; Sun et 101 al., 2018), are the most popular for in situ treatments of agricultural soils because of their 102 efficiency, low cost and eco-friendliness compared to physical and chemical remediation. 103 Consequently, they are sustainable techniques and an attractive research area in remediation. 104 By using the powerful diversity of microorganisms, several curative bioremediation methods 105 have been developed in the last decades. Among them, bioaugmentation has proven its 106 efficiency for the removal of pesticides in soil (Lebeau, 2011; Cycoń et al., 2017; Morillo and 107 Villaverde, 2017). However, several factors influence the success rate of this strategy, such as 108 environmental parameters (soil moisture content, $\mathrm{pH}$, temperature, organic matter content), 
109 inoculum load and survival rate of exogenous microorganisms, or pesticide concentration and 110 bioavailability (Lebeau, 2011; Vandermaesen et al., 2016; Cycoń et al., 2017). To overcome 111 some of these limitations, this approach has sometimes been combined with bio-stimulation

112 (e.g. Raimondo et al. (2020)) and other mitigation strategies (e.g. grassed buffer strips and 113 constructed wetlands) to reduce pesticide inputs into surface water and groundwater 114 (Reichenberger et al., 2007; Swartjes and Van der Aa, 2020). Nevertheless, the effectiveness 115 of these approaches was highly variable. It would thus be very advantageous to develop new 116 strategies able to decrease the time of pesticide residence in soil in order to avoid its adsorption 117 and to limit its diffusion into the various environment compartments by rapid biodegradation. 118 The present study focused on the herbicide 2,4-D (2,4-dichlorophenoxyacetic acid), which 119 belongs to the phenoxy-acid chemical family (Mitchell and Hamner, 1944). It is a widely-used 120 herbicide in agricultural and urban areas around the world for efficient control of broad-leaved 121 weeds in cereal crops and lawns (Peterson et al., 2016). 2,4-D is an analogue of the 122 phytohormone auxin (indole-3-acetic acid, IAA) resulting in uncontrolled growth and death for 123 plants prone to the molecule. It targets dicots and its recommended agronomic field rate is 750 $124 \mathrm{~g}$ of active ingredient (a.i.) ha ${ }^{-1}$ (EFSA, 2014). Taking its water solubility into account and $\mathrm{K}_{\mathrm{d}}$ 125 values (547 $\mathrm{mg} \mathrm{L}^{-1}$ and $1.81-4.28 \mathrm{~L} \mathrm{~kg}^{-1}$, respectively), 2,4-D is classified as having a moderate 126 potential for ground water contamination, which is also proven by GUS (Groundwater Ubiquity 127 Score) values of $2-2.7$ (Farenhorst et al., 2008; Pfeiffer, 2010; EFSA, 2014). Nevertheless, it 128 has been quantified worldwide in ground water, sometimes reaching concentrations exceeding $1291 \mu \mathrm{g} / \mathrm{L}$ (Brauns et al., 2018; ADES, 2019; Muszyński et al., 2020). 2,4-D is also frequently 130 detected in surface water: in 50\% of the samples in France in 2018 (NAIADES, 2019) and also 131 all around the world (Ensminger et al., 2013; Brauns et al., 2018; Horn et al., 2019; de Castro 132 Lima et al., 2020; Muszyński et al., 2020). As 2,4-D was shown to lead to numerous adverse 133 effects on non-target aquatic organisms, plants and human life (Smith et al., 2017; Dehnert et 
134 al., 2018; Islam et al., 2018; Zuanazzi et al., 2020), considerable efforts must be made to find 135 remediation solutions.

136 Microorganisms are the main drivers of 2,4-D degradation in soil (Peterson et al., 2016).

137 The model strain Cupriavidus necator JMP134 (formerly Alcaligenes eutrophus, Ralstonia 138 eutropha and Waustersia eutropha), which is able to use 2,4-D as the sole carbon source (Don 139 and Pemberton, 1981), has been the most studied. It was notably used to investigate the 140 biodegradation pathways of this herbicide (You and Ghosal, 1995; Leveau et al., 1999; 141 Laemmli et al., 2000). The $C$. necator JMP134 strain possesses the well-described plasmid $142 p$ JP4 that contains the degrading-gene cluster $t f d$ (Plumeier et al., 2002; Trefault et al., 2004). 143 Each $t f d$ gene encodes an enzyme involved in each of the 7 steps of 2,4-D mineralization. 144 Among these genes, $t f d A$ encodes for 2,4-D/ $\alpha$-ketoglutarate dioxygenase (TfdA) involved in 145 the first step of the herbicide degradation. Hence its frequent use as a molecular marker for the 146 degradation potential of 2,4-D in the environment (Stibal et al., 2012; Mierzejewska et al., 147 2019). Curative 2,4-D bioaugmentation assays, using between $10^{5}$ to $10^{8} \mathrm{CFU} / \mathrm{g}^{-1}$ soil of various 148 degrading-strains, were carried out in soil slurry (Inoue et al., 2012; Chang et al., 2015), in 149 reactor (Pepper et al., 2002), in sieved or amended soil microcosms (Dejonghe et al., 2000; Xia 150 et al., 2017) or more recently in combination with other mitigation strategies (Yang et al., 2018; 151 Barba et al., 2021). The removal of 2,4-D has also been investigated in soil microcosms 152 following simultaneous application of the herbicide and its degrading-strain (Önneby et al., 153 2010). This interesting approach increases the direct contact between the pesticide and its 154 degrading-microorganism enhancing its biodegradation in real time, thus avoiding adsorption 155 processes. Moreover, in such an approach, the exogenous degrading-microorganisms must be 156 efficient for only a short period of time.

157 Thus here, we implemented this preventive bioremediation method in the actual context of 158 a realistic farming practice, allowing sustainable agriculture to be promoted and reducing both 
159 the 2,4-D contamination in agricultural soils and the risk of leaching and runoff in aquatic

160 ecosystems. This strategy consists of simultaneously applying the formulated 2,4-D herbicide as DAM ${ }^{\circledR}$ and its mineralizing Cupriavidus necator JMP134 strain in a planted soil, in order to optimize the conditions for its biodegradation, just after its action and before its diffusion to the surrounding ecosystems. The experiment was carried out with a laboratory microcosm

164 approach under controlled conditions. Herbicide dissipation and mineralization but also 165 herbicidal efficiency, survival of the added degrading strain and impact on the structure of 166 edaphic bacterial community were assessed.

\section{Materials and methods}

2.1. Model herbicide and soil

The herbicide 2,4-D (2,4-dichlorophenoxyacetic acid, $\geq 98 \%$ purity) and [ring- $\left.{ }^{14} \mathrm{C}\right]-2,4-\mathrm{D}$

172 (analytical-grade purity $>99 \%$, specific activity $4.6 \times 10^{8} \mathrm{~Bq} \mathrm{mmol}^{-1}$ ) were purchased from

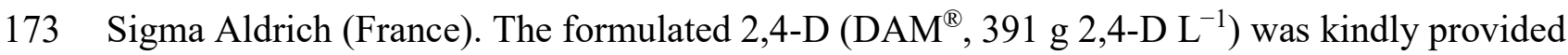
174 by Agriphar (now UPL OpenAg, France). The OECD sandy loam standard soil 5M was 175 purchased from LUFA Speyer (Germany). The physico-chemical properties and characteristics 176 of the soil are indicated in Table 1.

2.2. Bacterial strain

179 The edaphic 2,4-D-degrader Cupriavidus necator JMP134 strain was purchased from the 180 German Collection of Microorganisms and Cell Cultures (DSMZ) (DSM number: 4058). Prior 181 to the experiment, we checked for rifampicin-resistant microorganisms on Rif-LB plates (must 182 be absent) from a suspension of the OECD standard soil 5M. Then, as already used to 183 specifically enumerate a bacterial strain in soil (Schreiter et al., 2014; Strauss et al., 2015; 
184 Sharma et al., 2017), a chromosomal rifampicin resistance (Rif $)$ mutation was induced in the 185 C. necator strain (Karunakaran and Davies, 2000; Lyu and Zhao, 2014). To achieve this goal, C. necator JMP134 strain was cultivated in $5 \mathrm{~mL}$ LB broth overnight at $28{ }^{\circ} \mathrm{C}$. After centrifugation $(8,000 \mathrm{~g}, 15 \mathrm{~min})$, the pellet was washed in $5 \mathrm{~mL}$ of $\mathrm{NaCl} 0.8 \%$ and spread on LB agar plate supplemented with $150 \mu \mathrm{g} \mathrm{mL}^{-1}$ of rifampicin (Sigma Aldrich, France, $\geq 97 \%$ purity). After $48 \mathrm{~h}$ of incubation at $28^{\circ} \mathrm{C}$, spontaneous Rif ${ }^{\mathrm{r}}$ mutants were obtained. Their ability to mineralize pure and formulated 2,4-D $\left(\mathrm{DAM}^{\circledR}\right)$ was tested and found to be the same as that 191 of the parent strain.

\subsection{Preparation of inoculum}

194 The $\operatorname{Rif}^{\mathrm{r}}$ C. necator JMP134 mutant (called later C. necator Rif $^{\mathrm{T}}$ ) was cultivated overnight 195 at $28{ }^{\circ} \mathrm{C}$ in $25 \mathrm{~mL}$ of $\mathrm{LB}$ broth containing $50 \mu \mathrm{g} \mathrm{mL}^{-1}$ rifampicin and $50 \mathrm{mg} \mathrm{L}^{-1}$ 2,4-D under 196 orbital agitation at $150 \mathrm{rpm}$ in $50 \mathrm{~mL}$ Erlenmeyer flasks. The bacterial culture was then centrifuged $(8,000 \mathrm{~g}, 15 \mathrm{~min})$ and the pellet was washed twice in $20 \mathrm{~mL}$ of sterile $\mathrm{NaCl} 0.8 \%$

198 before being resuspended in $10 \mathrm{~mL}$ sterile Volvic ${ }^{\circledR}$ water. In parallel, the colony forming units

199 enumeration $\left(\mathrm{CFU} \mathrm{mL} \mathrm{m}^{-1}\right)$ was carried out to ensure that the theoretical expected bacterial 200 concentration was spread on microcosms (see below). The correlation between $\mathrm{OD}_{600 \mathrm{~nm}}$ measurements and $\mathrm{CFU} \mathrm{mL} \mathrm{mL}^{-1}$ (one $\mathrm{OD}_{600 \mathrm{~nm}}$ unit corresponds to $610^{8} \mathrm{CFU} \mathrm{mL}^{-1}$ ) was performed by spreading serial dilutions of culture on LB agar plates and counting the colonies after $48 \mathrm{~h}$ of incubation at $28^{\circ} \mathrm{C}$.

\subsection{Microcosm setup and sampling}

Ninety-six microcosms were prepared by adding $100 \mathrm{~g}$ dry weight (dw) of OECD soil in 207 each crystal polystyrene box (length: $90 \mathrm{~mm}$, width: $60 \mathrm{~mm}$ and height: $50 \mathrm{~mm}$ ), previously 208 checked for their absence in 2,4-D adsorption. The humidity of each soil microcosm was then 
209 adjusted to $20 \%$ (corresponding to $50 \%$ of its maximal Water Holding Capacity (WHC))

210 before the sowing of 4 seeds of 2,4-D-insensitive wheat (Récital variety, kindly provided by

211 INRAe Crouël, France) per microcosm. After the germination of wheat (two days at $20^{\circ} \mathrm{C} \pm 2$

$212{ }^{\circ} \mathrm{C}$ ), 24 seeds of 2,4-D-sensitive white mustard (Sinapis alba) were planted in each microcosm.

213 Four replicates were carried out for each sampling time. Microcosms were randomly placed in

214 a unique enclosure of $150 \mathrm{~mm}$ height, covered with porous plastic film allowing air exchange

215 while limiting soil dehydration and incubated for 2 weeks in an experimental room at $20^{\circ} \mathrm{C} \pm$

$2162{ }^{\circ} \mathrm{C}$, with a day/night cycle $(14 / 10 \mathrm{~h})$ ensured by an artificial light (Osram-L-36W/964, 750

217 lux $)$. The treatments were applied on each microcosm surface $\left(5,400 \mathrm{~mm}^{2}\right) 5$ days after the

218 beginning of sowing.

219 Four different treatments were carried out by spreading $2 \mathrm{~mL}$ of Volvic ${ }^{\circledR}$ water 220 supplemented with herbicide at the agronomic recommended dose (4.23 $\mu \mathrm{g}$ of $2,4-\mathrm{D} \mathrm{g}^{-1} \mathrm{dw}_{\mathrm{w}}$ 221 soil, corresponding to $1.08 \mu \mathrm{L}$ of $\mathrm{DAM}^{\circledR}$ per microcosm) (24D) or not (control, H2O), and 222 inoculated with $C$. necator Rif $^{\mathrm{r}}$ only $\left(10^{5} \mathrm{CFU} \mathrm{g}{ }^{-1} \mathrm{dw}\right.$ of soil) (INOC) or not (NI). The sprays 223 were performed using a TG-470 airbrush (Fraulein $3^{\circ} 8$; flume diameter $=0.3 \mathrm{~mm}$ ). Soil water 224 content was adjusted every 2-3 days with Volvic ${ }^{\circledR}$ water all along the experiment.

225 Four randomly chosen replicates from each treatment were immediately sacrificed $(\mathrm{n}=4)$

226 after the spray (day 0) to quantify the initial doses of 2,4-D and bacteria applied. Then, the 227 sampling was performed on days 2, 4, 7, 9 and 15. For each sampling date, the number of living 228 plants was counted and the herbicidal efficiency was evaluated by visual observation of plant 229 survival. Photos were also taken on days $0,1,2,4,7,9,15$ to calculate the total leave surface 230 coverage after treatment by using the Fiji software (Schindelin et al., 2012). The plants and the 231 roots were removed, and the soil was mixed before being sub-sampled for further analyses (see 232 below). Enumeration of $C$. necator Rif $^{\mathrm{r}}$ and 2,4-D mineralization kinetics were carried out on 
233 fresh soil samples. Quantitative PCR, 16S metabarcoding and herbicide quantification were

234 obtained from $-20{ }^{\circ} \mathrm{C}$ soil frozen aliquots.

2.5. Quantification of 2,4-D in soil

\subsubsection{2,4-D extraction from soil}

238 The herbicide was extracted from $5 \mathrm{~g}$ of thawed soil by adding $20 \mathrm{~mL}$ of $\mathrm{MeOH} / \mathrm{H}_{2} \mathrm{O}(4 / 1$

$239 \mathrm{v} / \mathrm{v}$ ) in centrifuge tubes. Samples were stirred for $24 \mathrm{~h}$ using an orbital shaker at $50 \mathrm{rpm}$ and

240 room temperature. After centrifugation $(15,000 \mathrm{~g}$ for $15 \mathrm{~min})$, the supernatant was filtered on a

$2410.45 \mu \mathrm{m}$ syringe PVDF filter (after checking the lack of sorption on 2,4-D on this filter) and

242 concentrated in a Thermo Scientific SpeedVac concentrator without heating. The dried residue

243 was then dissolved in $500 \mu \mathrm{L}$ methanol, vortexed and injected on HPLC. The soil was spiked

244 with standard 2,4-D solutions at different concentrations and submitted to the same protocol.

245 The recovery percentage was $89 \pm 2 \%$.

246 2.5.2. Analysis by HPLC

247 The herbicide concentrations of soil liquid extracts were determined by HPLC on an Agilent 2481100 apparatus (Courtaboeuf, France) equipped with a reverse-phase column (C18 Zorbax 249 Eclipse Plus column, $75 \mathrm{~mm} \times 4.6 \mathrm{~mm}, 3.5 \mu \mathrm{m}$ ) at $22{ }^{\circ} \mathrm{C}$ and a diode array detector set at $\lambda=$ 250222 and $285 \mathrm{~nm}$. The mobile phase was composed of aqueous $\mathrm{H}_{3} \mathrm{PO}_{4}(0.01 \% \mathrm{v} / \mathrm{v}, \mathrm{pH}=2.9)$ 251 (A) and acetonitrile (B) at a flow rate of $1 \mathrm{~mL} \cdot \mathrm{min}^{-1}$. Gradient (linear): $0-1 \mathrm{~min}: 20 \% \mathrm{~B}$; 1-7 $252 \min : 20-70 \%$ B; 7-8 min: 70-100 \% B; 8-9 min: 100-20 \% B; 9-10.5 min: 20\% A. Injection 253 volume: $30 \mu \mathrm{L}$. Each sample was analyzed twice.

\section{2.5.3. Modelling of 2,4-D dissipation kinetics}

255 The kinetics of 2,4-D dissipation in soil were fitted with the DoseResp function of the 256 OriginPro V8 software (Origin Lab Corporation, USA) characterized by the following 257 equation: $C_{t}=\left(C_{0}-C_{f}\right) /\left[1+10^{D T 50-t(p)}\right] . t$ is the incubation time, $C_{t}$ the $2,4-\mathrm{D}$ concentration at 
time $t, C_{0}$ the initial concentration of 2,4-D, $C_{f}$ the final concentration of 2,4-D, $p$ the dissipation rate of $2,4-\mathrm{D}$ and $D T 50$ the time required to reduce the concentration by $50 \%$.

\subsection{Survival of $C$. necator Rif $^{\mathrm{r}}$ in soil}

One gram of mixed soil was taken and diluted in $1 \mathrm{~mL}$ of sterile $\mathrm{NaCl} 0.8 \%$. After

263 homogenization, serial dilutions were sprayed on LB agar plate containing $50 \mu \mathrm{g} \mathrm{mL}^{-1}$ of both 264 rifampicin and cycloheximide. The plates were then incubated during $48 \mathrm{~h}$ at $28{ }^{\circ} \mathrm{C}$ for $C$. necator Rif ${ }^{\mathrm{r}}$ enumeration. The number of $C$. necator Rif $^{\mathrm{r}}$ was expressed as $\mathrm{CFU} \mathrm{g}^{-1}$ of dry 266 weight $(\mathrm{dw})$ soil.

\subsection{2,4-D mineralization kinetics in soil}

269 The ability of soil microorganisms to mineralize 2,4-D was determined at each sampling 270 date by radiorespirometry analysis (Soulas, 1993). Briefly, $20 \mathrm{~g}$ of the various previously 271 collected fresh soil samples, adjusted to $80 \%$ of its WHC, were treated with $2,4-\mathrm{D}\left(2.5 \mathrm{mg} \mathrm{kg}^{-}\right.$ $\left.272{ }^{1} \mathrm{dw}\right)$ and $\left[\mathrm{ring}^{14} \mathrm{C}\right]-2,4-\mathrm{D}(1.7 \mathrm{Kbq})$, and incubated in a radiorespirometer at $20{ }^{\circ} \mathrm{C}$ in the dark 273 during one month. ${ }^{14} \mathrm{C}$-carbon dioxide resulting from the mineralization of ${ }^{14} \mathrm{C}-2,4-\mathrm{D}$ was 274 trapped in $5 \mathrm{~mL}$ of $0.2 \mathrm{M}$ sodium hydroxide solution placed in the respirometer. The sodium 275 hydroxide trapping solutions were regularly changed and the amount of the trapped ${ }^{14} \mathrm{C}$-carbon 276 dioxide was determined with a liquid scintillation counter (Packard 1900 TR-Tricarb) after 277 adding $10 \mathrm{~mL}$ of scintillation fluid (ACSII, Amersham). A segmented regression model 278 (Muggeo, 2003) was used to estimate the maximum mineralization potential rate of the ${ }^{14} \mathrm{C}$ 279 2,4-D. The slope of the $1^{\text {st }}$ regression line is considered to be the maximum mineralization 280 potential rate. 
DNA was directly extracted from $250 \mathrm{mg}$ of soil samples collected after different times of incubation as recommended by ISO 11063 derived from the method described by MartinLaurent et al. (2001). Briefly, soil samples were submitted to mechanical and chemical lysis. Soil and cell debris were discarded by centrifugation and proteins were eliminated by sodium acetate precipitation. The nucleic acids were precipitated with cold isopropanol, washed with $70 \%$ ethanol and then purified by passage through affinity and exclusion columns. The soil DNA extracts were quantified with the Quant-iT ${ }^{\mathrm{TM}}$ PicoGreen ${ }^{\circledR}$ dsDNAassay kit according to manufacturer' recommendations and stored at $-20{ }^{\circ} \mathrm{C}$ until use.

\subsubsection{Quantitative PCR analysis}

Prior to run qPCR assay, the absence of PCR inhibitors in the DNA extracts was assessed 294 as described previously in ISO 17601 (ISO 17601, 2006, 17). The abundance of total bacterial 295 community was estimated by qPCR targeting 16S rDNA with 341_F and 534_R universal primers (López-Gutiérrez et al., 2004). The abundance of 2,4-D degrading bacterial community was measured by qPCR targeting tfdA gene with tfdA_F and tfdA-R primers described by

298 Bælum et al. (2008). qPCR assays were done in a ViiA $7^{\mathrm{TM}}$ thermocycler (life Technologies, 299 Carlsbad, CA, USA) in a $15 \mu \mathrm{L}$ volume containing $250 \mathrm{ng}$ of T4 Gene 32 product (Qbiogene, $300 \mathrm{UK}), 2 \mathrm{ng}$ of soil DNA and $1 \mu \mathrm{M}$ of each primer. The amplification conditions were as follows: $30115 \mathrm{~min}$ at $95^{\circ} \mathrm{C} ; 30$ cycles of $15 \mathrm{~s}$ at $95^{\circ} \mathrm{C}, 30 \mathrm{~s}$ at $60{ }^{\circ} \mathrm{C}$ for $16 \mathrm{~S}$ rDNA or $54{ }^{\circ} \mathrm{C}$ for $t f d A$ and $30230 \mathrm{~s}$ at $72{ }^{\circ} \mathrm{C}$; one melting cycle was realized from 55 to $95^{\circ} \mathrm{C}$ by incremental temperature of $3030.2{ }^{\circ} \mathrm{C} \mathrm{s}^{-1}$. Standard curves were obtained using serial dilutions of linearized plasmids 304 containing appropriated cloned targeted gene sequence. Ct values outside the range of the 305 standard curve or for which melting curves differed from the standard were removed. Four 306 independent replicates for each treatment and three NTCs (non-template control) were used for 307 both qPCR assays. 
2.9. 16S metabarcoding

\subsubsection{Amplicon generation and MiSeq sequencing}

311 Amplicons were generated and sequenced as previously described (Romdhane et al., 2019).

312 Briefly, the bacterial 16S rRNA gene V3-V4 hyper variable regions were firstly amplified with 313 overhang adapters to allow the subsequent addition of Illumina Nextera indexes sequences.

314 First-step PCR amplicons were then used as template for a second step PCR using unique 315 multiplex primers pair combinations for each sample. The amplicons were cleaned-up using 316 sequalPrep $^{\mathrm{TM}}$ Normalization plate kit 96-well (Invitrogen) and followed by equimolar pooling.

317 Sequencing was performed on MiSeq (Illumina, $2 \times 250 \mathrm{bp}$ ) using the MiSeq reagent kit v2 (500

318 cycles). Demultiplexing and trimming of Illumina adaptors and barcodes was done with

319 Illumina MiSeq Reporter software (version 2.5.1.3).

\subsubsection{Sequencing analysis}

321 The sequence data were analysed using an in house developed Jupyter Notebooks (Kluyver 322 et al., 2016) piping together different bioinformatics tools. Briefly, R1 and R2 sequences were 323 assembled using PEAR (Zhang et al., 2014) with default settings. Further quality checks were 324 conducted using the QIIME pipeline (J Gregory Caporaso et al., 2010) and short sequences (< $325400 \mathrm{bp}$ ) were removed. Reference based and de novo chimera detection, as well as clustering 326 in OTUs were performed using VSEARCH (Rognes et al., 2016) and the adequate reference 327 databases (Greengenes' representative set of sequences). The identity thresholds were set at 94 $328 \%$ for $16 \mathrm{~S}$ rRNA gene data based on replicate sequencing of a bacterial mock community 329 containing 40 bacterial species. Representative sequences for each OTU were aligned using 330 PyNAST (J. G. Caporaso et al., 2010) and a 16S rRNA gene phylogenetic tree was constructed 331 using FastTree (Price et al., 2010). Taxonomy was assigned using UCLUST (Edgar, 2010) and 332 the latest released Greengenes database v.05/2013 (McDonald et al., 2012). $\alpha$-Diversity metrics 
and UniFrac distance matrices (Lozupone et al., 2011) were calculated based on rarefied OTU tables (21 000 sequences per sample). Sequences were deposited to the SRA at NCBI under the accession number PRJNA566399.

2.10. Statistical analyses

Statistical analyses were carried out using RStudio (Version 1.1.456). The factors (modalities) were Treatment (NI H2O, INOC H2O, NI 24D, INOC 24D) and Time (D0, D1, D2, D4, D7, D9, D15). Statistical differences in relative leave surface coverage, 2,4-D persistence in soil (DT 50$), \alpha$-diversity indexes of soil microbial communities and abundance of $C$. necator Rif $^{\mathrm{r}}$ in soil were assessed using one-way ANOVA followed by separate post hoc comparisons

343 (Tukey's test, $P<0.05$ ). Normality and homogeneity of variance were checked prior to 344 ANOVA analysis (Shapiro's and Levene's tests, respectively, $P<0.05$ ) and data that were not normally distributed were transformed using logarithmic, square, square root or Box-Cox functions. The effect of the treatments on $\beta$-diversity was assessed by performing permutational multivariate analysis of variance on the unweighted and weighted unifrac distance matrices (PERMANOVA), using the Adonis function of the R package Vegan (version 2.5-5).

\section{Results and Discussion}

\subsection{Herbicide efficiency of 2,4-D}

The soil microcosms containing wheat (insensitive to 2,4-D) and mustards, chosen as a

354 model of sensitive plant (dicot) and as a potential competitor of wheat (Haghighi, 2019), were exposed to the formulated 2,4-D (24D) or not (control, H2O), and inoculated with C. necator Rif $^{\mathrm{r}}$ (INOC) or not (NI). At the beginning of the experiment, the development and appearance 357 of wheat and mustard plants were similar whatever the treatments (Figure 1). A visual 
observation indicated an effect of 2,4-D from day 1 , mustards being completely killed in the corresponding microcosms (NI 24D treatment) while these plants were still alive after 15 days in the $\mathrm{NI} \mathrm{H} 2 \mathrm{O}$ and INOC $\mathrm{H} 2 \mathrm{O}$ treatments (Figure 1). As expected, these results confirmed the efficiency of the NI 24D treatment used in the present study to remove mustards (sensitive species). Interestingly, the inoculation of the 2,4-D-mineralizing $C$. necator Rif $^{\mathrm{r}}$ strain concomitantly to the herbicide did not reduce the efficiency of the herbicide. Indeed, similarly to the NI 24D treatment, all mustard plants were killed within 15 days in the INOC 24D treatment (Figure 1). The kinetic of 2,4-D mineralization by C. necator Rif $^{\mathrm{r}}$ strain was therefore slow enough to permit the foliar uptake of the herbicide in the sensitive plants which takes place in just a few hours (Barrier and Loomis, 1957; Knoche and Bukovac, 1999). These results were confirmed by the analyses of total leave surface coverage (Figure 2). After only one day of incubation, significant differences in leaf-coverage were observed between treatments $(\mathrm{P}<$ 0.001), the mustard leaves showing a slight curling effect in the treated 2,4-D soils. Both treatments receiving 2,4-D, alone (NI 24D) or in mixture with the C. necator Rif $^{\mathrm{r}}$ strain (INOC 24D), experienced the lowest surface coverage. Furthermore, no significant difference was

373 observed between NI H2O vs. INOC H2O, and NI 24D vs. INOC 24D. These results indicate

374 that the presence of exogenous $C$. necator Rif $^{\mathrm{r}}$ strain i) did not impact the growth of mustard 375 and wheat and ii) did not reduce the efficiency of 2,4-D. Besides, the visual observation revealed a slight negative effect of 2,4-D on wheat plants (less developed and less robust leaves compared to NI $\mathrm{H} 2 \mathrm{O}$ and INOC $\mathrm{H} 2 \mathrm{O}$ treatments). This is not surprising because, although

378 wheat is not sensitive to 2,4-D, it has already been shown that this herbicide can impact wheat 379 yield at all growth stages, mainly due to a decrease in the number of kernels per spikelet and a 380 reduction of the numbers of spikes per plant and spikelets per spike (Pinthus and Natowitz, 1967; Islam et al., 2018; Oliveira et al., 2019; Scholtes et al., 2019). 
3.2. 2,4-D dissipation and mineralization potential in soil

\subsubsection{2,4-D dissipation in soil}

After a lag phase of about 4 days, apparently necessary to activate the degrading genes of the indigenous microflora, a significant dissipation of 2,4-D was observed in soil treated with the herbicide (NI 24D), with a dissipation rate of $0.33 \pm 0.11$ day $^{-1}$ and a $\mathrm{DT}_{50}$ value of $7.40 \pm$ 0.64 days (Figure 3 and Table 2), leading to a $94 \%$ decrease of the initial 2,4-D amount within 15 days. The half-life obtained is similar to that observed in aerobic soils ( DT $_{50}=6.2$ days) (Reregistration Eligibility Decision (RED) 2,4-D, 2005) but lower than the mean half-life average values (12.6 days) collected from the datasets from laboratory studies (Wang et al., 2018). Indeed, the 2,4-D dissipation in soil can be very variable depending on the indigenous degrader concentration, organic matter content, moisture and temperature (Bouseba et al., 2009; Yang et al., 2018).

The inoculation of the C. necator Rif ${ }^{\mathrm{r}}$ strain, previously grown in LB medium supplemented with 2,4-D, concomitantly to the herbicide in soil (INOC 24D), suppressed the lag phase before herbicide dissipation. Under these conditions, the 2,4-D dissipation rate was increased $(0.47 \pm$ 0.06 day $^{-1}$ ) and its $\mathrm{DT}_{50}$ was reduced to $2.34 \pm 0.19$ days compared to the NI $24 \mathrm{D}$ soil. Thus, 4 days after treatment when the 2,4-D dissipation just started in the NI 24D condition, a decrease of about $85 \%$ of the $2,4-\mathrm{D}$ initial concentration was already observed, leading to a complete dissipation of the herbicide within 7 days (Figure 3 and Table 2). Therefore, the INOC 24D treatment reduced the persistence of 2,4-D by a 3-fold factor compared to the NI 24D treatment $(\mathrm{P}<0.05)$. Note that comparison of the 2,4-D mineralizing kinetics between the natural $C$. necator strain and its mutant showed no significant difference. This preventive bioremediation process thus reduced the risk of 2,4-D leaching and runoff into water bodies where it is currently detected (Brauns et al., 2018; Islam et al., 2018; Horn et al., 2019; NAIADES, 2019; de Castro Lima et al., 2020). Faster pesticide dissipation accordingly reduced its transfer into the 
environment. The preventive bioremediation could also provide the means to better protect the culture and avoid a decrease of productivity. Some studies have evidenced 2,4-D causing many

410 injuries to crops, despite its theoretical selectivity (Islam et al., 2018; Oliveira et al., 2019;

411 Scholtes et al., 2019).

\subsubsection{2,4-D mineralization potential in soil}

414 The evolution of ${ }^{14} \mathrm{CO}_{2}$ from ${ }^{14} \mathrm{C}-2,4-\mathrm{D}$ was monitored to estimate mineralization potential 415 of 2,4-D microbial guild extemporarily. Each previous fresh soil sample for each date was 416 supplemented by ${ }^{14} \mathrm{C}-2,4-\mathrm{D}$ to this end and the mineralization percentage was monitored by 417 radiorespirometry. The maximum potential rate of ${ }^{14} \mathrm{C}-2,4-\mathrm{D}$ mineralization was calculated 418 from modelled mineralization kinetics. It was found to be rather low $\left(<5 \%\right.$ of ${ }^{14} \mathrm{C}-2,4-\mathrm{D}$ per 419 day) and stable throughout the experiment in the control (NI H2O) (Figure 4). It was always 420 significantly higher in the inoculated microcosms (INOC H2O and INOC 24D) than in the control (NI H2O) $(\mathrm{P}<0.001)$. As compared to the NI H2O treatment, the inoculation of $C$. necator Rif $^{\mathrm{r}}$ led to a 4- and 5-fold increase in the rate of mineralization of INOC H2O and INOC 24D, respectively. Overall, these results show for the first time that the mineralization potential 424 of 2,4-D in soil was enhanced by simultaneous application of the degrading strain. This is a major advantage of preventive bioremediation, which aims at reducing the soil contamination by mineralization (i.e. without producing degradation products).

427 The maximum rate of mineralization was significantly higher in the INOC 24D treatment 428 than in the INOC H2O (after 2, 7, 9 and 15 days) $(\mathrm{P}<0.001)$. In addition, after a four-day lag 429 phase, the rate of mineralization in the NI 24D microcosm increased dramatically to reach 430 values similar to those of INOC 24D treatment. This natural mineralization for the NI 24D 431 treatment could be explained by the presence of indigenous degraders as already reported in 432 other soils (Bælum et al., 2008; Zabaloy et al., 2010). Furthermore, knowing that the 2,4-D was 
433 also shown to be moderately persistent ( $\mathrm{DT}_{50}=45$ days) in aerobic aquatic environments and

434 highly persistent $\left(\mathrm{DT}_{50}=231\right.$ days $)$ in anaerobic terrestrial and aquatic environments

435 (Reregistration Eligibility Decision (RED) 2,4-D, 2005), it is of great importance to mineralize

436 it as soon as possible after spraying onto the soil before it reaches the surrounding environments.

3.3. Abundance of $C$. necator Rif $^{\mathrm{T}}$ in soil

C. necator Rif $^{\mathrm{r}}$ was inoculated at $10^{5} \mathrm{cfu} \mathrm{g}^{-1} \mathrm{dw}$ soil. In both inoculated soil microcosms, $C$.

440 necator Rif $^{\mathrm{r}}$ strain was maintained around $10^{4}-10^{5} \mathrm{cfu} \mathrm{g}^{-1} \mathrm{dw}$ soil during the first four days of

441 incubation (Figure 5). C. necator $\operatorname{Rif}^{\mathrm{T}}$ was enumerated at a significantly higher value in the

442 INOC 24D microcosms than in the inoculated INOC $\mathrm{H}_{2} \mathrm{O}$ ones at days $7(\mathrm{P}<0.01), 9$ and 15

443 ( $\mathrm{P}<0.001)$. We could hypothesize that the exposure to $2,4-\mathrm{D}$ provides a temporary selective

444 advantage for microorganisms capable of using the herbicide as carbon and energy source and

445 led to the growth of $C$. necator Rif $^{\mathrm{r}}$ population as long as it is bioavailable (Macur et al., 2007;

446 Zabaloy et al., 2010). Then, a plateau of the C. necator Rif $^{\mathrm{T}}$ population was observed from day

44710 in the INOC 24D treatment (Figure 5) probably because of complete mineralization of the

448 2,4-D already at day 7. Thus, it seems that these conditions of preventive bioremediation with

449 a simultaneous spray of 2,4-D and the $C$. necator Rif $^{\mathrm{r}}$ strain can overcome some of the limiting

450 factors influencing the success of curative bioaugmentation processes in soil such as i) sorption

451 of pesticides on soil particles and formation of bound residues leading to a decrease of

452 bioavailability and biodegradability, and ii) competition between the inoculated strain and

453 indigenous microorganisms and its survival (Cycon et al., 2017), even when the 2,4-D herbicide

454 was removed. Indeed, at day 15, no growth was observed anymore but the strain is still able to

455 survive. This is not surprising since Cupriavidus necator can easily adapt its growth to nutrient

456 availability in the environment. Indeed, this strain is described as an optional predator for other

457 bacteria and is able to switch from autotrophic to heterotrophic metabolism depending the 
environmental conditions (Makkar and Casida Jr, 1987; Holt et al., 1994). Similar results have

459 already been observed, the 2,4-D degraders being able to survive and remain at high abundance

460 for about 1 month after herbicide exposure has stopped (Merini et al., 2007; Zabaloy et al.,

$4612010)$

462 These results were confirmed by the $16 \mathrm{~S}$ rRNA sequence affiliated to $C$. necator Rif $^{\mathrm{r}}$ (similarity 463 above 95\%) which were retrieved in both inoculated microcosms but in higher abundances in 464 the INOC $24 \mathrm{D}$ treatment $(4.4 \pm 2.0$ reads per 100,000$)$ than in the INOC H2O one $(0.7 \pm 0.3$ 465 reads per 100,000). No sequences affiliated to $C$. necator Rif $^{\mathrm{r}}$ were found in the non-inoculated microcosms (NI $\mathrm{H}_{2} \mathrm{O}$ and NI 24D) confirming that no cross-contamination by $C$. necator Rif $^{\mathrm{r}}$

467 occurred during the experiment.

3.4. Abundance of 2,4-D bacterial degraders

The abundance of 2,4-D microbial degraders was monitored throughout the incubation by estimating the relative abundance of $t f d A$ (coding for an enzyme involved in 2,4-D 472 mineralization) per 16S rRNA sequence (Figure 6). We observed that 2,4-D bacterial degraders 473 were present in rather large amount in the control soil NI H2O averaging $5.5 t f d A$ sequences 474 per thousand 16S rRNA and remained stable during the 15 day-experimentation (Figure 6). For 475 the non-inoculated soils, the abundance of $t f d A$ gene copy number increased in the presence of 2,4-D (NI 24D) after 9 days of incubation and was still higher after 15 days than in the non477 treated soils (NI H2O). These results indicate that the indigenous 2,4-D degrader populations 478 need to be stimulated by the herbicide before being able to grow and activate their 2,4-D 479 mineralization capacity as shown in Figures 3 and 4. This induction of 2,4-D degrading gene 480 expression has already been described (Trefault and Guzmán, 2009) and may contributes to the 481 accelerated biodegradation observed with edaphic microbial communities chronically exposed 482 to 2,4-D (Arbeli and Fuentes, 2007). 
For the inoculated soils, the quantity of degrader in untreated soil i.e. without 2,4-D (INOC

$484 \mathrm{H} 2 \mathrm{O}$ ) was similar to the NI H2O and remained stable throughout the experiment but increased

485 after only 4 days after inoculation in the treated soils (INOC 24D). The C. necator RifR strain

486 being already acclimatised to the presence of 2,4-D (see 2.3), the delay for the increase of 2,4-

487 D degrading community size was shortened as shown by the enumeration of C. necator Rif in

488 soil samples (Figure 5). Lack of lag phase observed for the dissipation of 2,4-D in the soil

489 (Figure 3) and its mineralization potential (Figure 4) corroborate the former facts.

3.5. Impact of 2,4-D on soil bacterial communities

NGS analysis of the soil bacterial community revealed that the soil was composed of about 3200 OTUS (similarity threshold of 0.94). Proteobacteria (34\%), Acidobacteria (31\%),

494 Gemmatimonadetes ( $8 \%$ ) and Bacteroidetes $(7 \%)$ were the 4 most abundant phyla representing up to $80 \%$ of sequences in all. $\alpha$-diversity was estimated by a richness (observed species), a phylogenetic diversity (PD whole tree), and a composite evenness (Simpson reciprocal) index (Figure S1). We found that the soil bacterial $\alpha$-diversity was significantly affected by time in the microcosm study however none of the treatments (INOC, 24D), nor their interaction (preventive bioremediation) had a significant effect on $\alpha$-diversity indices of the bacterial community (Figure S1). In addition, as revealed by PERMANOVA performed on PCoAs using both unweighted (uw) and weighted (w) unifrac distance matrices, the $\beta$-diversity was affected by the time $(\mathrm{Puw}$ and $\mathrm{Pw}<0.01)$ but not by the pesticide treatment $(\mathrm{Puw}=0.119, \mathrm{Pw}=0.129)$ nor the strain inoculation $(\mathrm{Puw}=0.253, \mathrm{Pw}=0.181)($ Figure $\mathrm{S} 2)$. Our results are consistent

504 with several studies showing that the 2,4-D herbicide treatment, used at the recommended 505 agricultural dose, has little or no impact on bacterial communities (Bouseba et al., 2009; Zabaloy et al., 2010; Inoue et al., 2012) and that the inoculation of a 2,4-D degrading507 Cupriavidus sp. strain did not disturb the soil indigenous microorganisms (Chang et al., 2015). 


\section{Conclusion}

510 The present work demonstrates that preventive bioremediation is a promising tool for a new

511 agricultural strategy to reduce the persistence of pesticides in soil and their subsequent risk of

512 transfer into the environment. Moreover, our results show that the simultaneous application of

513 the 2,4-D herbicide and its degrader, Cupriavidus necotor JMP134, did not compromise

514 herbicide efficiency and led to a threefold reduction of its persistence in soil without

515 significantly affecting the indigenous bacterial community. Further studies (e.g. other

516 herbicide/degrading strains, other soil types and climatic conditions, larger scale) are under

517 investigation to validate the "proof of concept" of this technique in agriculture.

\section{Acknowledgements}

520 This work was supported by the Région Auvergne, the French Ministry for Higher

521 Education and Research and the European Regional Development Fund. The authors 522 acknowledge Frédérique Bonnemoy for her valuable help in setting up soil microcosms, 523 Anthony Auclair for his contribution to a first round of analyses of the 16S rRNA amplicon 524 sequence dataset and Philip Hoggan for English reviewing.

\section{References}

ADES (2019) Portail national d'accès aux données sur les eaux souterraines. http://www.ades.eaufrance.fr.

530 Arbeli, Z. and Fuentes, C.L. (2007) Accelerated biodegradation of pesticides: An overview of the phenomenon, its basis and possible solutions; and a discussion on the tropical dimension. Crop Prot 26: 1733-1746.

Bælum, J., Nicolaisen, M.H., Holben, W.E., Strobel, B.W., Sørensen, J., and Jacobsen, C.S. (2008) Direct analysis of tfdA gene expression by indigenous bacteria in phenoxy acid amended agricultural soil. ISME J 2: 677-687. 
Barba, S., Villaseñor, J., Rodrigo, M.A., and Cañizares, P. (2021) Biostimulation versus bioaugmentation for the electro-bioremediation of 2,4-dichlorophenoxyacetic acid polluted soils. J Environ Manage 277: 111424.

Barrier, G.E. and Loomis, W.E. (1957) Absorption and translocation of 2,4dichlorophenoxyacetic acid and $\mathrm{P}^{32}$ by Leaves. Plant Physiol 32: 225-231.

Blake, C., Christensen, M.N., and Kovács, Á.T. (2020) Molecular aspects of plant growth promotion and rotection by Bacillus subtilis. Mol Plant-Microbe Interactions ${ }^{\circledR} 34$ : 12 25.

Bouseba, B., Zertal, A., Beguet, J., Rouard, N., Devers, M., Martin, C., and Martin-Laurent, F. (2009) Evidence for 2,4-D mineralisation in Mediterranean soils: impact of moisture content and temperature. Pest Manag Sci 65: 1021-1029.

Brauns, B., Jakobsen, R., Song, X., and Bjerg, P.L. (2018) Pesticide use in the wheat-maize double cropping systems of the North China Plain: Assessment, field study, and implications. Sci Total Environ 616-617: 1307-1316.

Caporaso, J. G., Bittinger, K., Bushman, F.D., DeSantis, T.Z., Andersen, G.L., and Knight, R. (2010) PyNAST: a flexible tool for aligning sequences to a template alignment. Bioinformatics 26: 266-267.

Caporaso, J Gregory, Kuczynski, J., Stombaugh, J., Bittinger, K., Bushman, F.D., Costello, E.K., et al. (2010) QIIME allows analysis of high-throughput community sequencing data. Nat Methods 7: 335-336.

de Castro Lima, J.A.M., Labanowski, J., Bastos, M.C., Zanella, R., Prestes, O.D., de Vargas, J.P.R., et al. (2020) "Modern agriculture" transfers many pesticides to watercourses: a case study of a representative rural catchment of southern Brazil. Environ Sci Pollut Res 27: 10581-10598.

Chang, Y.-C., Reddy, M.V., Umemoto, H., Sato, Y., Kang, M.-H., Yajima, Y., and Kikuchi, S. (2015) Bio-Augmentation of Cupriavidus sp. CY-1 into 2,4-D Contaminated Soil: Microbial Community Analysis by Culture Dependent and Independent Techniques. PLOS ONE 10: e 0145057.

Cycoń, M., Mrozik, A., and Piotrowska-Seget, Z. (2017) Bioaugmentation as a strategy for the remediation of pesticide-polluted soil: A review. Chemosphere 172: 52-71.

Dehnert, G.K., Freitas, M.B., DeQuattro, Z.A., Barry, T., and Karasov, W.H. (2018) Effects of low, subchronic exposure of 2,4-Dichlorophenoxyacetic acid (2,4-D) and commercial 2,4-D formulations on early life stages of fathead minnows (Pimephales promelas). Environ Toxicol Chem 37: 2550-2559.

Dejonghe, W., Goris, J., El Fantroussi, S., Hofte, M., De Vos, P., Verstraete, W., and Top, E.M. (2000) Effect of Dissemination of 2,4-Dichlorophenoxyacetic Acid (2,4-D) Degradation Plasmids on 2,4-D Degradation and on Bacterial Community Structure in Two Different Soil Horizons. Appl Environ Microbiol 66: 3297-3304.

Del Buono, D., Terzano, R., Panfili, I., and Bartucca, M.L. (2020) Phytoremediation and detoxification of xenobiotics in plants: herbicide-safeners as a tool to improve plant efficiency in the remediation of polluted environments. A mini-review. Int $J$ Phytoremediation 1-15.

Don, R.H. and Pemberton, J.M. (1981) Properties of six pesticide degradation plasmids isolated from Alcaligenes paradoxus and Alcaligenes eutrophus. J Bacteriol 145: 681-686.

Edgar, R.C. (2010) Search and clustering orders of magnitude faster than BLAST. Bioinformatics 26: 2460-2461.

EFSA (2014) Conclusion regarding the peer review of the pesticide risk assessment of the active substance 2,4-D. EFSA J 12(9): 1-78. 
Ensminger, M.P., Budd, R., Kelley, K.C., and Goh, K.S. (2013) Pesticide occurrence and aquatic benchmark exceedances in urban surface waters and sediments in three urban areas of California, USA, 2008-2011. Environ Monit Assess 185: 3697-3710.

European Commission (2020) Communication from the Commission to the European Parliament, the Council, the European Economic and Social Committee and the Committee of the Regions: A Farm to Fork Strategy for a fair, healthy and environmentally-friendly food system. COM2020381 Final.

Farenhorst, A., Londry, K.L., Nahar, N., and Gaultier, J. (2008) In-field variation in 2,4-D mineralization in relation to sorption and soil microbial communities. $J$ Environ Sci Health Part B 43: 113-119.

Ferreira, C.M.H., Soares, H.M.V.M., and Soares, E.V. (2019) Promising bacterial genera for agricultural practices: An insight on plant growth-promoting properties and microbial safety aspects. Sci Total Environ 682: 779-799.

Haghighi, A. (2019) Ecological fitness of tribenuron methyl (ALS inhibitor herbicide) susceptible and resistant biotypes of wild mustard in competition with wheat. Appl Ecol Environ Res 17: 6227-6240.

Holt, J.G., Krieg, N.R., Sneath, P.H., Staley, J.T., and Williams, S.T. (1994) Bergey's Manual of determinate bacteriology.

Horn, S., Pieters, R., and Bøhn, T. (2019) A first assessment of glyphosate, 2,4-D and Cry proteins in surface water of South Africa. South Afr J Sci 115: 74-80.

Inoue, D., Yamazaki, Y., Tsutsui, H., Sei, K., Soda, S., Fujita, M., and Ike, M. (2012) Impacts of gene bioaugmentation with pJP4-harboring bacteria of 2,4-D-contaminated soil slurry on the indigenous microbial community. Biodegradation 23: 263-276.

Islam, F., Wang, J., Farooq, M.A., Khan, M.S.S., Xu, L., Zhu, J., et al. (2018) Potential impact of the herbicide 2,4-dichlorophenoxyacetic acid on human and ecosystems. Environ Int 111: $332-351$.

ISO 17601 (2006) Soil quality - Estimation of abundance of selected microbial gene sequences by quantitative PCR from DNA directly extracted from soil.

Karunakaran, P. and Davies, J. (2000) Genetic Antagonism and Hypermutability inMycobacterium smegmatis. J Bacteriol 182: 3331-3335.

Kluyver, T., Ragan-Kelley, B., Pérez, F., Granger, B., Bussonnier, M., Frederic, J., et al. (2016) Jupyter Notebooks - a publishing format for reproducible computational workflows. In Positioning and Power in Academic Publishing: Players, Agents and Agendas. pp. 8790.

Knoche, M. and Bukovac, M.J. (1999) Spray application factors and plant growth regulator performance: II. Foliar uptake of gibberellic acid and 2,4-D. Pestic Sci 55: 166-174.

Köhl, J., Booij, K., Kolnaar, R., and Ravensberg, W.J. (2019) Ecological arguments to reconsider data requirements regarding the environmental fate of microbial biocontrol agents in the registration procedure in the European Union. BioControl 64: 469-487.

Laemmli, C.M., Leveau, J.H., Zehnder, A.J., and van der Meer, J.R. (2000) Characterization of a second tfd gene cluster for chlorophenol and chlorocatechol metabolism on plasmid pJP4 in Ralstonia eutropha JMP134 (pJP4). J Bacteriol 182: 4165-4172.

Lebeau, T. (2011) Bioaugmentation for in situ soil remediation: how to ensure the success of such a process. In Bioaugmentation, Biostimulation and Biocontrol. Singh, A., Parmar, N., and Kuhad, R.C. (eds). Berlin, Heidelberg: Springer Berlin Heidelberg, pp. 129186.

Légifrance (2019) Note technique du 19 juin 2019 relative à la déclinaison régionale du plan Ecophyto II+. https://www.legifrance.gouv.fr/circulaire/id/44764. 
Leveau, J.H., König, F., Füchslin, H., Werlen, C., Der Meer, V., and Roelof, J. (1999) Dynamics of multigene expression during catabolic adaptation of Ralstonia eutropha JMP134 (pJP4) to the herbicide 2, 4-dichlorophenoxyacetate. Mol Microbiol 33: 396406.

López-Gutiérrez, J.C., Henry, S., Hallet, S., Martin-Laurent, F., Catroux, G., and Philippot, L. (2004) Quantification of a novel group of nitrate-reducing bacteria in the environment by real-time PCR. J Microbiol Methods 57: 399-407.

Lozupone, C., Lladser, M.E., Knights, D., Stombaugh, J., and Knight, R. (2011) UniFrac: an effective distance metric for microbial community comparison. ISME J 5: 169-172.

Lyu, L.-D. and Zhao, G.-P. (2014) Determination of Rifampicin-resistance Mutation Frequency and Analysis of Mutation Spectra in Mycobacteria. BIO-Protoc 4: e1168.

Macur, R.E., Wheeler, J.T., Burr, M.D., and Inskeep, W.P. (2007) Impacts of 2,4-D application on soil microbial community structure and on populations associated with 2,4-D degradation. Microbiol Res 162: 37-45.

Makkar, N.S. and Casida Jr, L.E. (1987) Cupriavidus necator gen. nov., sp. nov.; a Nonobligate bacterial predator of bacteria in soil. Int J Syst Evol Microbiol 37: 323-326.

Marian, M. and Shimizu, M. (2019) Improving performance of microbial biocontrol agents against plant diseases. J Gen Plant Pathol 85: 329-336.

Martin-Laurent, F., Philippot, L., Hallet, S., Chaussod, R., Germon, J.C., Soulas, G., and Catroux, G. (2001) DNA extraction from soils: old bias for new microbial diversity analysis methods. Appl Environ Microbiol 67: 2354-2359.

McDonald, D., Price, M.N., Goodrich, J., Nawrocki, E.P., DeSantis, T.Z., Probst, A., et al. (2012) An improved Greengenes taxonomy with explicit ranks for ecological and evolutionary analyses of bacteria and archaea. ISME J 6: 610-618.

Merini, L.J., Cuadrado, V., Flocco, C.G., and Giulietti, A.M. (2007) Dissipation of 2,4-D in soils of the Humid Pampa region, Argentina: A microcosm study. Chemosphere 68: 259-265.

Mierzejewska, E., Baran, A., Tankiewicz, M., and Urbaniak, M. (2019) Removal and Ecotoxicity of 2,4-D and MCPA in Microbial Cultures Enriched with StructurallySimilar Plant Secondary Metabolites. Water 11: 1451-14567.

Mitchell, J.W. and Hamner, C.L. (1944) Polyethylene glycols as carriers for growth-regulating substances. Bot Gaz 105: 474-483.

Morillo, E. and Villaverde, J. (2017) Advanced technologies for the remediation of pesticidecontaminated soils. Sci Total Environ 586: 576-597.

Muggeo, V.M.R. (2003) Estimating regression models with unknown break-points. Stat Med 22: $3055-3071$.

Muszyński, P., Brodowska, M.S., and Paszko, T. (2020) Occurrence and transformation of phenoxy acids in aquatic environment and photochemical methods of their removal: a review. Environ Sci Pollut Res 27: 1276-1293.

NAIADES (2019) Données sur la qualité des eaux de surface. http://www.naiades.eaufrance.fr.

Oliveira, G.M.P. de, Gandolfo, M.A., Oliveira, R.B. de, Oliveira, S.M.P. de, and Martins, V.A. (2019) Potential drift and injury of herbicides sprayed in a wind tunnel. Eng Agríc 39: $75-82$.

Önneby, K., Jonsson, A., and Stenström, J. (2010) A new concept for reduction of diffuse contamination by simultaneous application of pesticide and pesticide-degrading microorganisms. Biodegradation 21: 21-29.

Ortiz-Hernandez, M.L., Castrajon-Godinez, M.L., Popoca-Ursino, E.C., and CervantesDecasac, F.R. (2018) Strategies for biodegradation and bioremediation of pesticides in 
the environment. In Strategies for bioremediation of organic and inorganic pollutants. Fuentes, M.S., Colin, V.L., Saez, J.M., pp. 95-115.

Pepper, I.L., Gentry, T.J., Newby, D.T., Roane, T.M., and Josephson, K.L. (2002) The role of cell bioaugmentation and gene bioaugmentation in the remediation of co-contaminated soils. Environ Health Perspect 110: 943-946.

Peterson, M.A., McMaster, S.A., Riechers, D.E., Skelton, J., and Stahlman, P.W. (2016) 2,4-D past, present, and future: A review. Weed Technol 30: 303-345.

Pfeiffer, M. (2010) Groundwater Ubiquity score (GUS). Pestic Train Resour.

Pinthus, M.J. and Natowitz, Y. (1967) Response of spring wheat to the application of 2,4-D at various growth stages. Weed Res 7: 95-101.

Plumeier, I., Perez-Pantoja, D., Heim, S., Gonzalez, B., and Pieper, D.H. (2002) Importance of different tfd genes for degradation of chloroaromatics by Ralstonia eutropha JMP134. $J$ Bacteriol 184: 4054-4064.

Price, M.N., Dehal, P.S., and Arkin, A.P. (2010) FastTree 2 - Approximately MaximumLikelihood Trees for Large Alignments. PLoS ONE 5: e9490.

Raimondo, E.E., Saez, J.M., Aparicio, J.D., Fuentes, M.S., and Benimeli, C.S. (2020) Coupling of bioaugmentation and biostimulation to improve lindane removal from different soil types. Chemosphere 238: 124512.

Reichenberger, S., Bach, M., Skitschak, A., and Frede, H.-G. (2007) Mitigation strategies to reduce pesticide inputs into ground- and surface water and their effectiveness; A review. Sci Total Environ 384: 1-35.

Reregistration Eligibility Decision (RED) 2,4-D, E. 738-R.-05-002 (2005) U.S. Environmental Protection Agency, Office of Prevention, Pesticides and Toxic Substances, Office of Pesticide Programs, U.S.

Rognes, T., Flouri, T., Nichols, B., Quince, C., and Mahé, F. (2016) VSEARCH: a versatile open source tool for metagenomics. PeerJ 4: e2584.

Romdhane, S., Spor, A., Busset, H., Falchetto, L., Martin, J., Bizouard, F., et al. (2019) Cover crop management practices rather than composition of cover crop mixtures affect bacterial communities in no-till agroecosystems. Front Microbiol 10: 1618.

Schindelin, J., Arganda-Carreras, I., Frise, E., Kaynig, V., Longair, M., Pietzsch, T., et al. (2012) Fiji: an open-source platform for biological-image analysis. Nat Methods 9: 676682.

Scholtes, A.B., Sperry, B.P., Reynolds, D.B., Irby, J.T., Eubank, T.W., Barber, L.T., and Dodds, D.M. (2019) Effect of soybean growth stage on sensitivity to sublethal rates of dicamba and 2,4-D. Weed Technol 33: 555-561.

Schreiter, S., Sandmann, M., Smalla, K., and Grosch, R. (2014) Soil Type Dependent Rhizosphere Competence and Biocontrol of Two Bacterial Inoculant Strains and Their Effects on the Rhizosphere Microbial Community of Field-Grown Lettuce. PLoS ONE 9: e103726.

Sharma, R., Paliwal, J.S., Chopra, P., Dogra, D., Pooniya, V., Bisaria, V.S., et al. (2017) Survival, efficacy and rhizospheric effects of bacterial inoculants on Cajanus cajan. Agric Ecosyst Environ 240: 244-252.

Smith, A.M., Smith, M.T., La Merrill, M.A., Liaw, J., and Steinmaus, C. (2017) 2,4dichlorophenoxyacetic acid (2,4-D) and risk of non-Hodgkin lymphoma: a metaanalysis accounting for exposure levels. Ann Epidemiol 27: 281-289.

Soulas, G. (1993) Evidence for the existence of different physiological groups in the microbial community responsible for 2,4-D mineralization in soil. Soil Biol Biochem 25: 443-449. 
Stibal, M., Bælum, J., Holben, W.E., Sørensen, S.R., Jensen, A., and Jacobsen, C.S. (2012) Microbial Degradation of 2,4-Dichlorophenoxyacetic Acid on the Greenland Ice Sheet. Appl Environ Microbiol 78: 5070-5076.

Strauss, S.L., Stover, J.K., and Kluepfel, D.A. (2015) Impact of biological amendments on Agrobacterium tumefaciens survival in soil. Appl Soil Ecol 87: 39-48.

Sun, S., Sidhu, V., Rong, Y., and Zheng, Y. (2018) Pesticide Pollution in Agricultural Soils and Sustainable Remediation Methods: a Review. Curr Pollut Rep 4: 240-250.

Swartjes, F.A. and Van der Aa, M. (2020) Measures to reduce pesticides leaching into groundwater-based drinking water resources: An appeal to national and local governments, water boards and farmers. Sci Total Environ 699: 134186.

Syed Ab Rahman, S.F., Singh, E., Pieterse, C.M.J., and Schenk, P.M. (2018) Emerging microbial biocontrol strategies for plant pathogens. Plant Sci 267: 102-111.

Trefault, N., De la Iglesia, R., Molina, A.M., Manzano, M., Ledger, T., Perez-Pantoja, D., et al. (2004) Genetic organization of the catabolic plasmid pJP4 from Ralstonia eutropha JMP134 (pJP4) reveals mechanisms of adaptation to chloroaromatic pollutants and evolution of specialized chloroaromatic degradation pathways. Environ Microbiol 6: 655-668.

Trefault, N. and Guzmán, L. (2009) Involvement of several transcriptional regulators in the differential expression of tfd genes in Cupriavidus necator JMP134. Int Microbiol 12: 97-106.

Vandermaesen, J., Horemans, B., Bers, K., Vandermeeren, P., Herrmann, S., Sekhar, A., et al. (2016) Application of biodegradation in mitigating and remediating pesticide contamination of freshwater resources: state of the art and challenges for optimization. Appl Microbiol Biotechnol 100: 7361-7376.

Wang, Y., Lai, A., Latino, D., Fenner, K., and Helbling, D.E. (2018) Evaluating the environmental parameters that determine aerobic biodegradation half-lives of pesticides in soil with a multivariable approach. Chemosphere 209: 430-438.

Xia, Z.-Y., Zhang, L., Zhao, Y., Yan, X., Li, S.-P., Gu, T., and Jiang, J.-D. (2017) Biodegradation of the Herbicide 2,4-Dichlorophenoxyacetic Acid by a New Isolated Strain of Achromobacter sp. LZ35. Curr Microbiol 74: 193-202.

Yang, Z., Xu, X., Dai, M., Wang, L., Shi, X., and Guo, R. (2018) Combination of bioaugmentation and biostimulation for remediation of paddy soil contaminated with 2,4-dichlorophenoxyacetic acid. J Hazard Mater 353: 490-495.

You, I.-S. and Ghosal, D. (1995) Genetic and molecular analysis of a regulatory region of the herbicide 2, 4-dichlorophenoxyacetate catabolic plasmid pJP4. Mol Microbiol 16: 321331.

Zabaloy, M.C., Garland, J.L., and Gomez, M.A. (2010) Assessment of the impact of 2,4dichlorophenoxyacetic acid (2,4-D) on indigenous herbicide-degrading bacteria and microbial community function in an agricultural soil. Appl Soil Ecol 46: 240-246.

Zhang, J., Kobert, K., Flouri, T., and Stamatakis, A. (2014) PEAR: a fast and accurate Illumina Paired-End reAd mergeR. Bioinformatics 30: 614-620.

Zuanazzi, N.R., Ghisi, N. de C., and Oliveira, E.C. (2020) Analysis of global trends and gaps for studies about 2,4-D herbicide toxicity: A scientometric review. Chemosphere 241: 125016. 


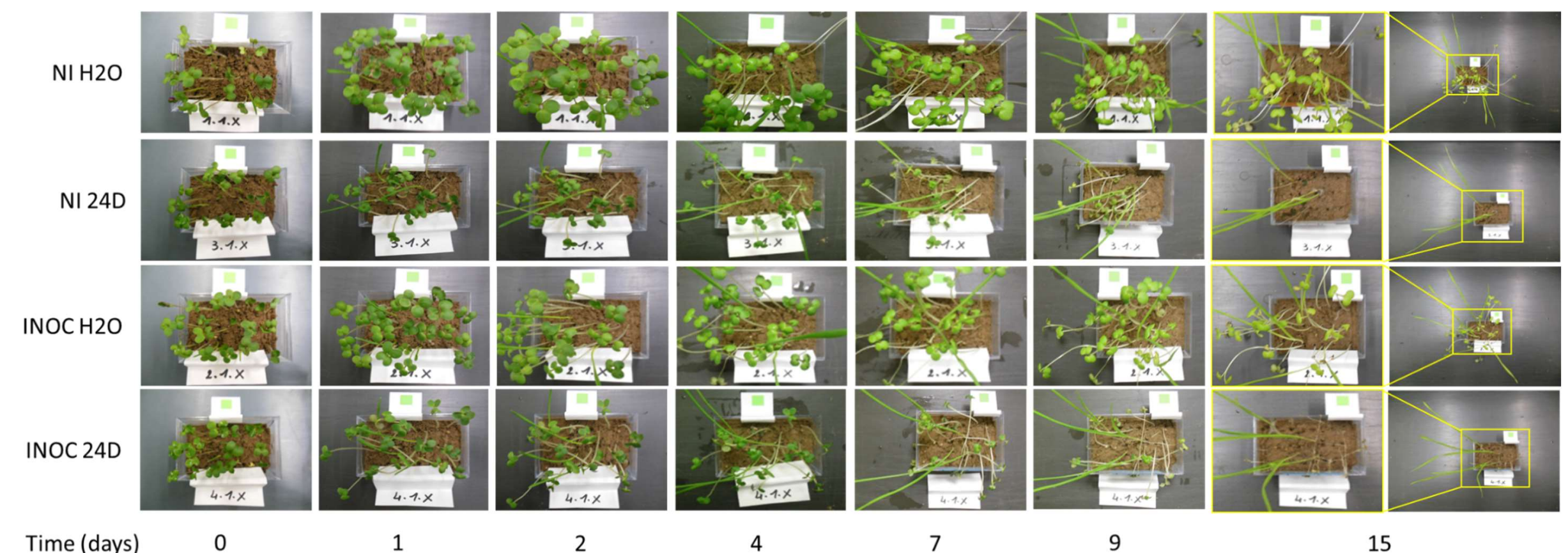

773 Figure 1. Top view of soil microcosms inoculated with C. necator Rif $^{\mathrm{r}}$ at $10^{5} \mathrm{cfu}^{-1} \mathrm{dw}$ soil (INOC) or not (NI) and treated with the agronomic

774 dose of formulated 2,4-D (24D) or not $\left(\mathrm{H}_{2} \mathrm{O}\right)$ along the experiment (0-15 days). One replicate per treatment has been selected as a representative 


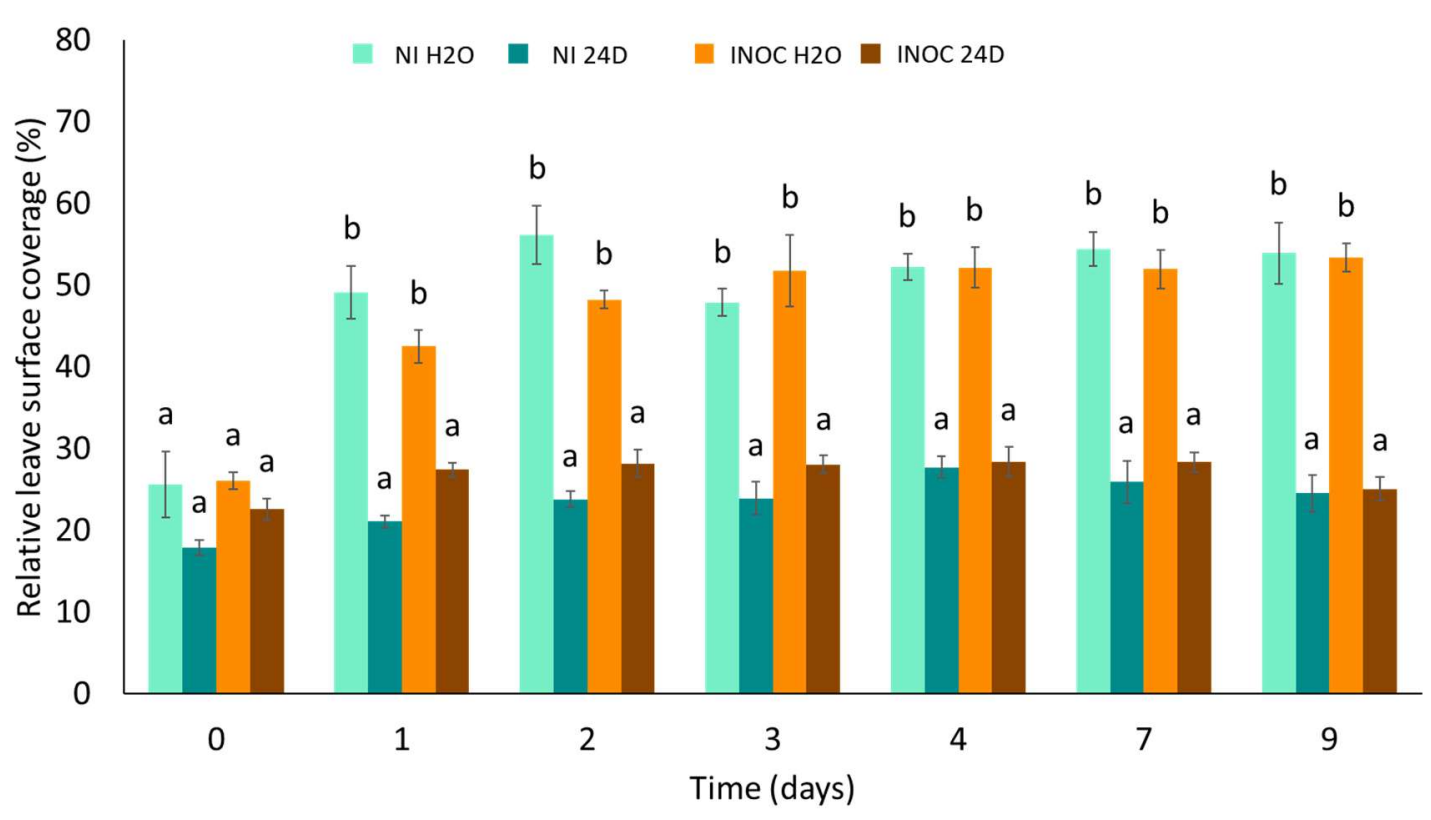

777 Figure 2. Evolution of total leave surface coverage over time expressed as a percentage of the 778 surface of soil microcosms inoculated with C. necator Rif $^{\mathrm{r}}$ at $10^{5} \mathrm{cfu} \mathrm{g}^{-1} \mathrm{dw}$ soil (INOC) or not 779 (NI) and treated with the agronomic dose of formulated 2,4-D (24D) or not $\left(\mathrm{H}_{2} \mathrm{O}\right)$. For each 780 date, statistical differences were indicated by lowercase letters $(\mathrm{a}<\mathrm{b})$, Tukey's test $(\mathrm{P}<0.05)$. 


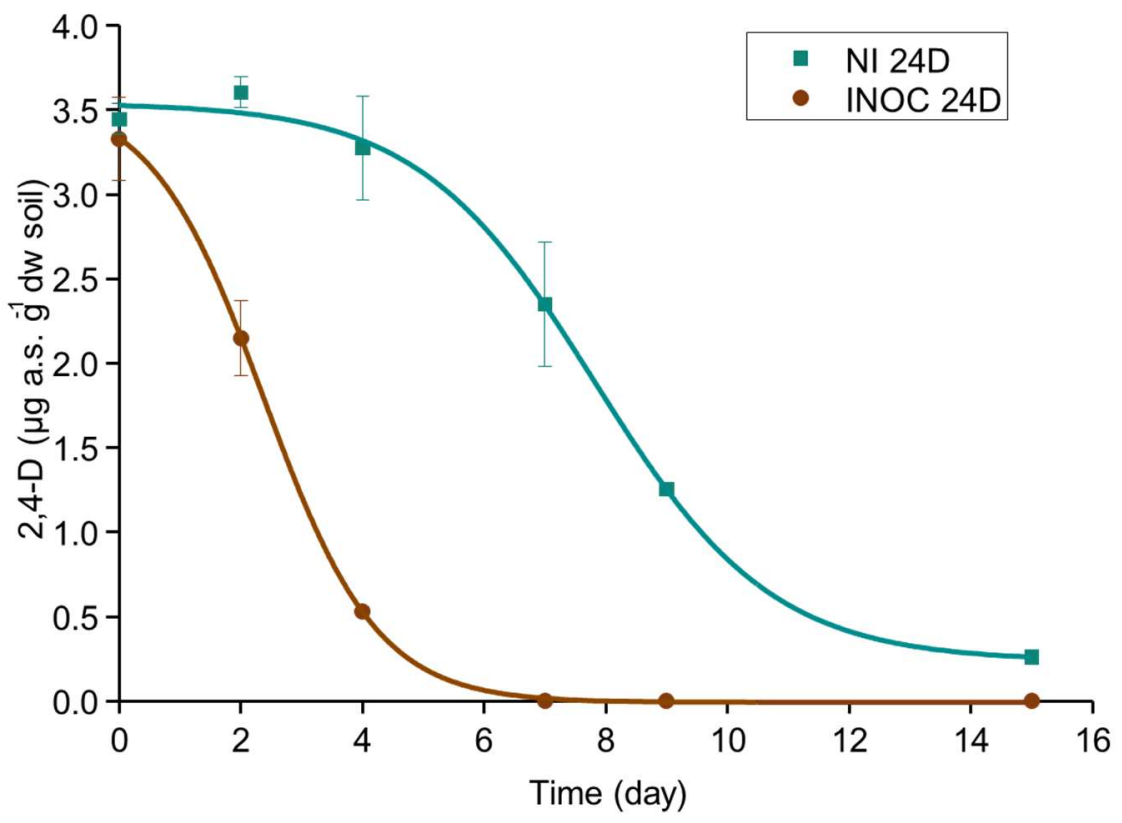

792

793 Figure 3. Dissipation kinetics of 2,4-D in soil. Microcosms were treated with the agronomical 794 dose of formulated 2,4-D and either inoculated with C. necator Rif $^{\mathrm{r}}$ at $10^{5} \mathrm{cfu} \mathrm{g}^{-1} \mathrm{dw}$ soil (INOC 795 24D) or not (NI 24D). The values are means \pm standard errors of experimental data $(n=4)$.

796

797

798

799

800

801

802

803

804

805

806

807

808 


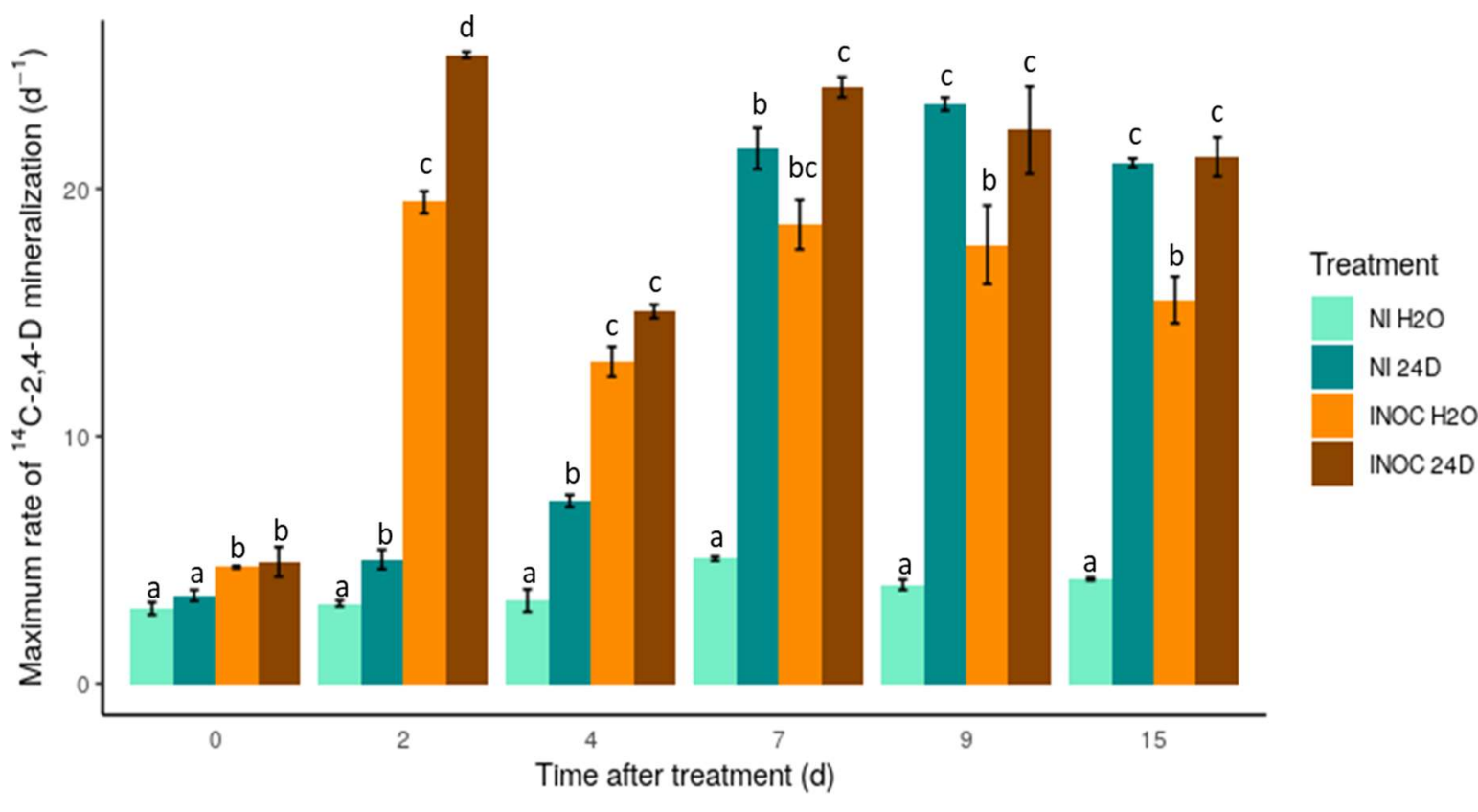

810

811 Figure 4. Maximum mineralization potential rate of the ${ }^{14} \mathrm{C}-2,4-\mathrm{D}$ at $0,2,4,7,9$ and 15 days

812 after treatment in soil microcosms inoculated with C. necator Rif $^{\mathrm{r}}$ at $10^{5} \mathrm{cfu} \mathrm{g}^{-1} \mathrm{dw}$ soil (INOC)

813 or not (NI) and treated with the agronomic dose of formulated 2,4-D (24D) or not $\left(\mathrm{H}_{2} \mathrm{O}\right)$. The

814 values are means \pm standard errors $(n=4)$. For a given date, different letters indicate significant

815 differences between treatments $(p<0.001)$.

816 


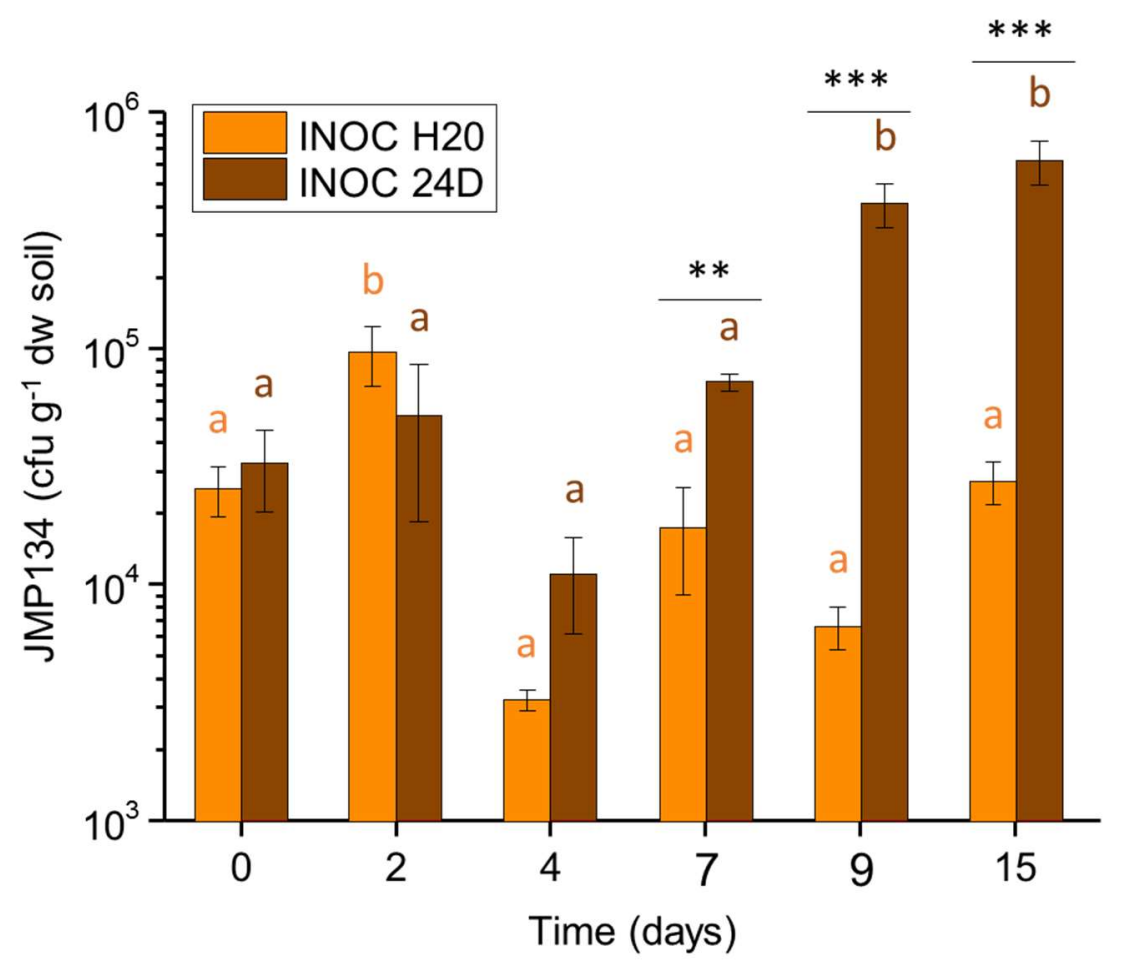

827

828 Figure 5. Abundance of C. necator Rif $^{\mathrm{r}}$ in the soil microcosms at 0, 2, 4, 7, 9 and 15 days after 829 treatment with $\mathrm{H}_{2} \mathrm{O}$ (INOC $\mathrm{H} 2 \mathrm{O}$ ) and 2,4-D (INOC 24D). The values are means \pm standard 830 errors $(n=4)$ of experimental data. Statistical differences (Tukey's test) were indicated for each 831 date by stars $\left(* * \mathrm{P}<0.01,{ }^{* * *} \mathrm{P}<0.001\right)$ and for each treatment by lowercase letters $(\mathrm{a}<\mathrm{b}, \mathrm{P}$ $832<0.05)$

833

834

835

836

837

838

839

840 


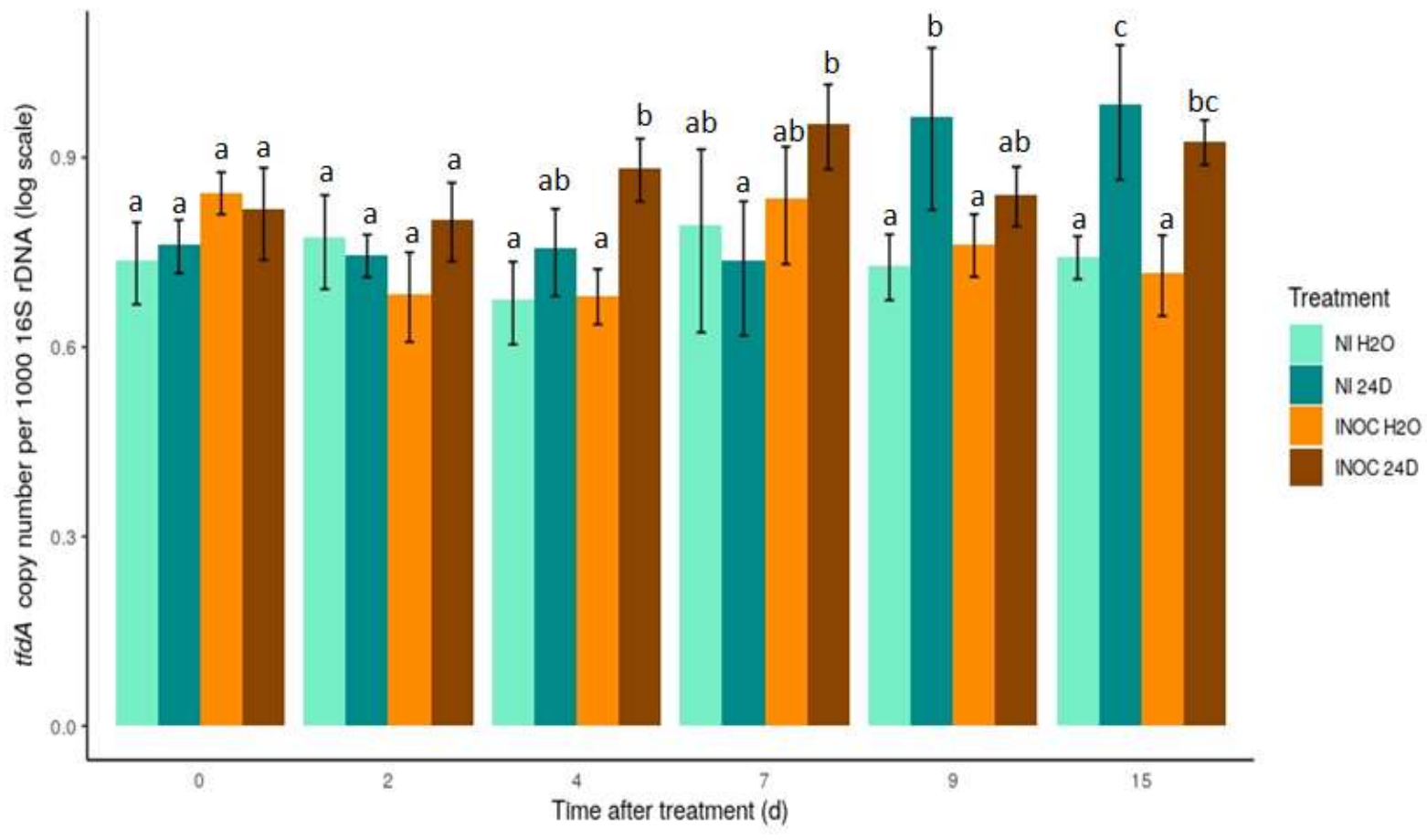

Figure 6. Relative abundance of 2,4-D degraders in the overall bacterial community at 0 ,

$8442,4,7,9$ and 15 days after treatment in soil microcosms inoculated with $C$. necator Rif $^{\mathrm{r}}$ at $10^{5}$ 845 cfu. $\mathrm{g}^{-1} \mathrm{dw}$ soil (INOC) or not (NI) and treated with the agronomic dose of formulated 2,4-D 846 (24D) or not $\left(\mathrm{H}_{2} \mathrm{O}\right)$. The values are means \pm standard errors $(n=4)$. At each time, different

847 letters indicate significant differences in $t f d A$ gene copy number $(\mathrm{P}<0.001)$. 
857 Table 1. Physico-chemical properties of 5M OECD standard soil (LUFA Speyer, Germany).

858 Values are means of different batch analyses \pm standard deviation. All values refer to dry matter.

859

\begin{tabular}{lllllcr}
\hline $\begin{array}{l}\text { Cationic } \\
\text { exchange } \\
\text { capacity } \\
\text { (meq / } 100 \mathrm{~g})\end{array}$ & $\begin{array}{l}\text { Organic } \\
\text { carbon } \\
\% \mathrm{C}\end{array}$ & $\begin{array}{l}\text { Nitrogen } \\
\% \mathrm{~N}\end{array}$ & $\begin{array}{l}\mathrm{pH}-\mathrm{value} \\
\left(0.01 \mathrm{M} \mathrm{CaCl}_{2}\right)\end{array}$ & $\begin{array}{l}\text { Maximum water } \\
\text { holding capacity } \\
(\mathrm{g} / 100 \mathrm{~g})\end{array}$ & $\begin{array}{l}\text { Particule } \\
\text { size }(\mathrm{mm})\end{array}$ & $\begin{array}{l}\text { Particule size } \\
\text { distribution } \\
(\%)\end{array}$ \\
\hline $17.7 \pm 3.7$ & $1.02 \pm 0.08$ & $0.13 \pm 0.01$ & $7.3 \pm 0.1$ & $40.1 \pm 2.4$ & & \\
& & & & & $0.002-0.05$ & $30.9 \pm 1.4$ \\
& & & & $0.05-2.0$ & $58.2 \pm 1.6$ \\
\hline
\end{tabular}

860

861

862

863

864

865

866

867

868

869

870

871

872

873

874

875

876

877 
878 Table 2. Parameters of 2,4-D dissipation kinetics in soil microcosms treated with agronomical 879 dose of formulated 2,4-D and either inoculated with C. necator Rif $^{\mathrm{r}}$ (INOC 24D) or not (NI 880 24D). Experimental data were fitted with the DoseResp model (OriginPro 8). The values are 881 means \pm standard errors of experimental data $(n=4)$. For each parameter, statistical differences

882 were indicated by lowercase letters $(\mathrm{a}<\mathrm{b})$, Tukey's test $(\mathrm{P}<0.01)$.

\begin{tabular}{llllll}
\hline & \multicolumn{5}{c}{ Model parameters } \\
\cline { 2 - 5 } Treatment & $C_{0}\left(\mu \mathrm{g}\right.$ a.s. $\mathrm{g}^{-1} \mathrm{dw}$ soil $)$ & $C_{f}\left(\mu \mathrm{g}\right.$ a.s. $\mathrm{g}^{-1} \mathrm{dw}$ soil $)$ & $p\left(\right.$ day $\left.^{-1}\right)$ & $D T_{50}($ day $)$ & $\mathrm{r}^{2}$ \\
\hline & & & & & \\
NI 24D & $3.77 \pm 0.18(\mathrm{a})$ & $0.19 \pm 0.11(\mathrm{a})$ & $0.33 \pm 0.11(\mathrm{a})$ & $7.40 \pm 0.64(\mathrm{~b})$ & $0.992 \pm 0.004$ \\
INOC 24D & $3.61 \pm 0.24(\mathrm{a})$ & $0.00 \pm 0.00(\mathrm{a})$ & $0.47 \pm 0.06(\mathrm{a})$ & $2.34 \pm 0.19(\mathrm{a})$ & $0.999 \pm 0.001$
\end{tabular}

$883 \quad C_{0}$ : initial concentration of 2,4-D; $C_{f}$ : final concentration of 2,4-D; $p$ : dissipation rate of 2,4-D; $D T_{50}$ : time

884 required to reduce the concentration by $50 \%$

885

886

887

888

889

890

891

892

893

894

895

896

897

898 
Potential of preventive bioremediation to reduce environmental contamination by pesticides in an agricultural context: a case study with the herbicide $2,4-D$

Louis Carles ${ }^{\mathrm{a}}$ b* , Fabrice Martin-Laurent ${ }^{\mathrm{c}}$, Marion Devers ${ }^{\mathrm{c}}$, Aymé Spor $^{\mathrm{c}}$, Nadine Rouard

Jérémie Beguet $^{\mathrm{c}}$, Pascale Besse-Hoggan ${ }^{\mathrm{b}}$, Isabelle Batisson ${ }^{\mathrm{a}}$

908

909 a Université Clermont Auvergne, CNRS, Laboratoire Microorganismes : Génome et 910 Environnement (LMGE), F-63000 Clermont-Ferrand, France

911 b Université Clermont Auvergne, CNRS, Sigma Clermont, Institut de Chimie de Clermont912 Ferrand (ICCF), F-63000 Clermont-Ferrand, France

$913 \quad{ }^{\mathrm{c}}$ Agroécologie, AgroSup Dijon, INRA, Univ. Bourgogne, F-21000 Dijon, France

$915 *$ Corresponding author:

916 Dr. Louis Carles

917 Now at: Department of Environmental Toxicology (Utox), Swiss Federal Institute of Aquatic 918 Science and Technology (Eawag), Dübendorf, Switzerland.

919 Überlandstrasse 133

9208600 Dübendorf

921 Switzerland

922 E-mail address: louis.carles@eawag.ch

923 Phone: +41587655449 

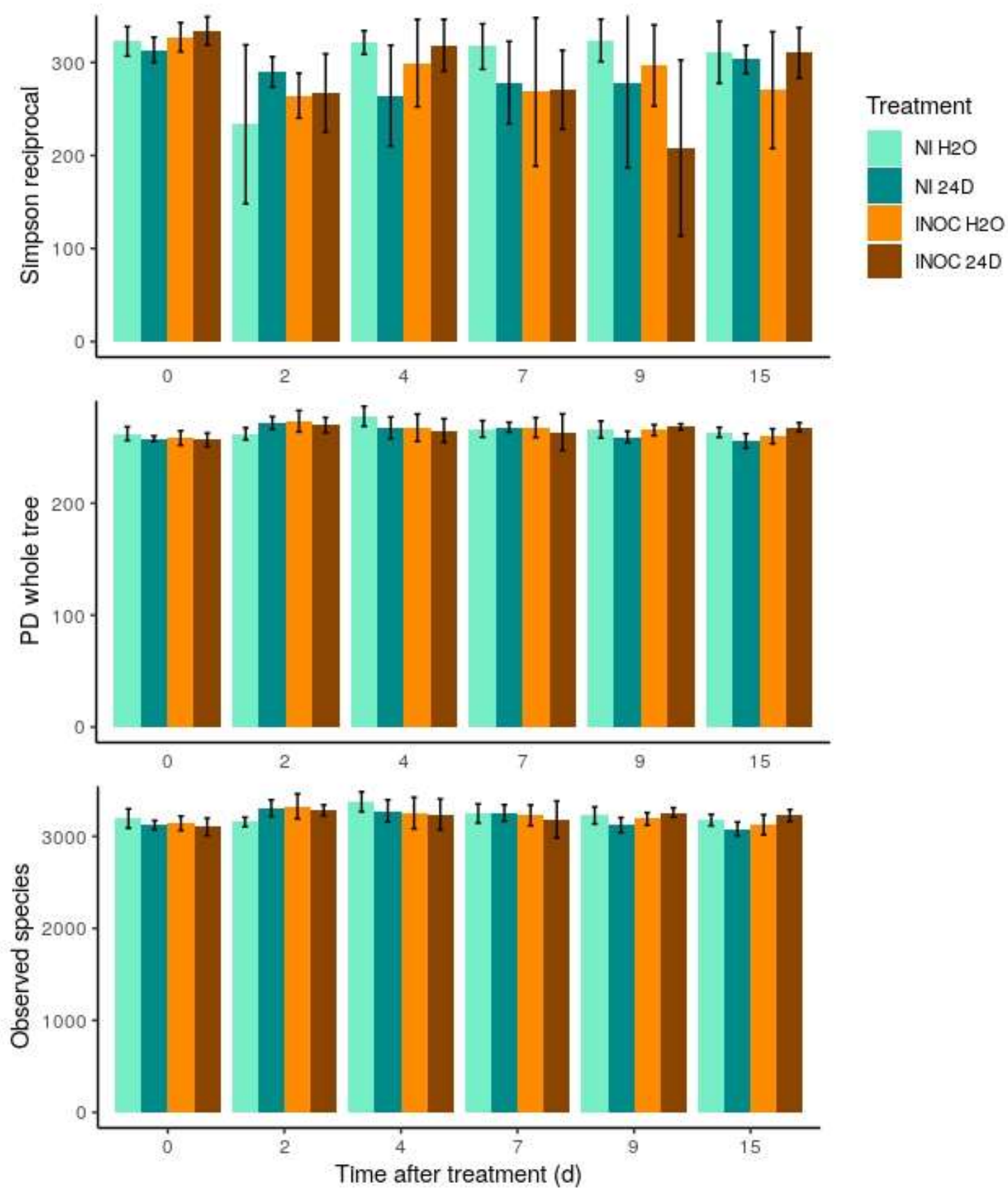

927 Figure S1. Bacterial $\alpha$-diversity indices. Simpson reciprocal, PD whole tree and observed

928 species indices were estimated at $0,2,4,7,9$ and 15 days after treatment in soil microcosms

929 inoculated with $C$. necator Rif $^{\mathrm{r}}$ at $10^{5} \mathrm{cfu} \mathrm{g}^{-1} \mathrm{dw}$ soil (INOC) or not (NI) and treated at the

930 agronomic dose of formulated 2,4-D (24D) or not $\left(\mathrm{H}_{2} \mathrm{O}\right)$. The values are means \pm standard

931 errors $(n=4)$. ANOVA indicated that neither inoculation nor 2,4-D treatment had impact on

932 the measured indices $(\mathrm{n}=4, \mathrm{p}<0.01)$. 

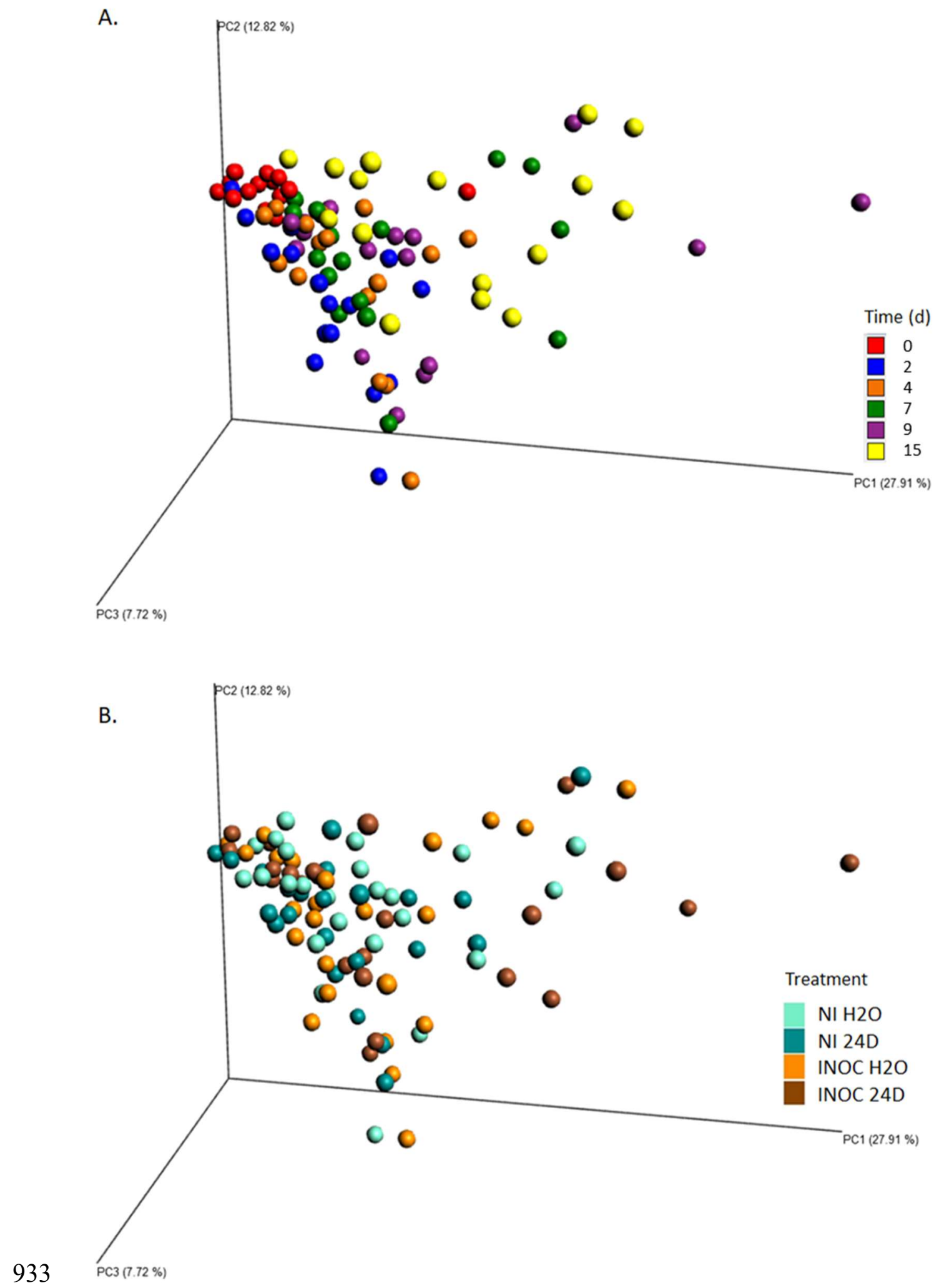

934 Figure S2. Bacterial $\beta$-diversity. PcoA of the weighted unifrac distance matrix obtained from

935 16S metabarcoding. A. The different colors represent the different sampling times. B. The dif936 ferent colours represent the different treatments. 